IMF Country Reports $\quad 20 / 73$

\title{
Sudan: Selected Issues
}




\section{INTERNATIONAL MONETARY FUND}

IMF Country Report No. 20/73

March 2020

\section{SUDAN}

\section{SELECTED ISSUES}

This Selected Issues paper on Sudan was prepared by a staff team of the International Monetary Fund as background documentation for the periodic consultation with the member country. It is based on the information available at the time it was completed on February 6, 2020.

\footnotetext{
Copies of this report are available to the public from International Monetary Fund $\bullet$ Publication Services PO Box $92780 \bullet$ Washington, D.C. 20090 Telephone: (202) 623-7430 • Fax: (202) 623-7201 E-mail: publications@imf.org Web: http://www.imf.org Price: $\$ 18.00$ per printed copy
}

\section{International Monetary Fund Washington, D.C.}




\section{INTERNATIONAL MONETARY FUND}

\section{SUDAN}

\section{SELECTED ISSUES}

February 6, 2020

Approved By

Middle East and Central

Asia Department
Prepared by Olusegun Akanbi, Qiaoe Chen, Mizuho Kida, and Marta Spinella

\section{CONTENTS}

ENHANCING GOVERNANCE AND REDUCING THE OPPORTUNITIES FOR CORRUPTION IN SUDAN_______ $\underline{\mathbf{4}}$

A. Introduction____ 4

B. Definition of Governance, Perception and Costs of Corruption ___ $\underline{\underline{5}}$

C. Fiscal Governance ___ _

D. Financial Sector Oversight ___ _ 11

E. Central Bank Governance and Operations ____ 11

F. Market Regulation____ 14

G. Rule of Law and Anti-Corruption Enforcement ____ 14

$\mathrm{H}$. Anti-Money Laundering and Combating the Financing of Terrorism (AML/CFT) and Anti-Corruption Framework____ $\underline{16}$

I. Concluding Remarks ___ $\underline{17}$

\section{FIGURES}

1. Selected Governance indicators $-\frac{7}{9}$

2. Biggest Obstacles to Firms' Operation ___

3. Level of Education and Health Spending__

4. Access to Services ___ $\frac{10}{10}$

5. Estimating Public Investment Efficiency ___

6. Macroeconomic Performance ___ ___ $\frac{13}{13}$

7. Evolution of Exchange Rates in Sudan ___ $\underline{13}$

8. To What Degree is the Following an Obstacle to the Current Operations of the Firm? ___ $\frac{15}{16}$

9. Corruption Perception by Firm Size ___ $\frac{16}{16}$

10. Corruption Perception by Industry ___ 
REVENUE MOBILIZATION_______

A. Background and Recent Trends___ 21

B. Cross-Country Comparison ___ $\underline{22}$

C. Successful Country Experiences in Mobilizing Tax Revenue ___ $\underline{23}$

D. How Can Sudan Mobilize More Tax Revenue?___ 24

E. Conclusions ___ $\underline{26}$

\section{FIGURES}

1. Components of Tax Revenue___ 21

2. Tax Revenue and Per Capita Income____

3. Cross-Country Tax Revenue____ $\frac{21}{23}$

4. Cross-Country Comparison of Sudan's Tax Revenue Performance, 2000-18__ $\underline{23}$

\section{TABLES}

1. Tax Rates in Selected Non-Resource-Rich MCD and SSA Countries ___ $\underline{22}$

2. Tax Revenue Scheme and Indicative Exemptions ___ 24

3. Exemptions from Customs Duty and VAT Imports___ $\underline{25}$

References______ $\underline{27}$

SUDAN'S OIL SECTOR: HISTORY, POLICIES, AND OUTLOOK __ $\underline{\mathbf{2}}$

A. The Booming Oil Sector Before the Secession of South Sudan __ $\underline{28}$

B. Complex Opaque Financial Flows, Weak Governance, and Large Subsidies __ $\underline{30}$

C. Removing Energy Subsidies and Reforming Oil Sector Governance ____ $\underline{35}$

\section{FIGURES}

1. Crude Oil Productions and Exports____

2. Inflation, Exchange Rate, and Fuel Subsidies___

3. Gap Between Domestic and International Fuel Prices___

4. Financial Flows in Energy Production and Consumption ___

5. Gasoline and Diesel Consumption Changes____ $\underline{34}$

TABLE

1. Main Oil Companies in Sudan____ $\underline{29}$

References_____ $\underline{37}$ 


\section{FIGURES}

1. The Structure of Financial System of Sudan __

2. Banking System Credit Structure by Borrowers ___

3. Banking System Credit Structure by Sector ___ $\underline{39}$ 


\title{
ENHANCING GOVERNANCE AND REDUCING THE OPPORTUNITIES FOR CORRUPTION IN SUDAN ${ }^{1}$
}

\author{
A. Introduction
}

1. A large body of literature and country analyses confirm that weak governance and corruption undermine economic growth, amplify income inequality and erode public trust in the institutions. Based on these findings, the IMF has revised its "Framework for Enhanced Engagement on Governance" 2 to better help its membership in addressing governance and corruption issues. The Framework, which builds on the 1997 Governance Policy, ${ }^{3}$ is designed to promote a "systematic, effective, candid and evenhanded engagement with member countries when governance vulnerabilities and corruption are judged to be macroeconomically critical". ${ }^{4}$ Sudan has been assessed to be one of the countries where such engagement should be a priority.

2. Overarching challenges in Sudan: fragility, lack of transparency and accountability, poor data quality. The analysis of governance performance and of the vulnerability to corruption in Sudan needs to take into account the inherent fragility of the country, its limited institutional capacity, the lack of reliable and timely data and, in general, an inadequate level of transparency, all of which are conducive to weak governance and make the effects of corruption, where present, particularly acute. Relatedly, the assessment exercise and engagement strategy need to strictly adhere to the elements designed in the IMF Guidance on Fragile and Conflict State (FCS). ${ }^{5}$ Fund advice should be wellinformed and tailored to economic settings and institutional constraints, accurately phased and timed to ensure realism and feasibility, based on authorities' ownership of reforms and coupled with capacity developments initiatives to avoid reversal of achievements.

3. This note provides a first stock-taking of the scale, main transmission channels and potential costs of poor governance and corruption in Sudan and offers preliminary recommendations. Measuring the effects of governance shortcomings and of corruption is usually difficult, not least because they are often disguised or hidden. Although over the years the literature has developed many indicators of corruption, as they are mostly based on perception and the dataset is often incomplete they should be interpreted with caution. ${ }^{6}$ This note uses qualitative and quantitative information, also collected in the field during the latest missions, measured against

\footnotetext{
${ }^{1}$ Prepared by Marta Spinella and Mizuho Kida, with contributions from Arz Murr. The authors are thankful to Alice French and Sebastiaan Pompe who provided helpful comments and constructive criticism to improve the note.

2 See IMF, "The Role of the Fund in Governance Issues-Review of the Guidance Note-Preliminary Considerations", 2017 and IMF, "Review of 1997 Guidance Note on Governance-A proposed Framework for Enhanced Fund Engagement," 2018.

${ }^{3}$ See IMF, "The Role of the IMF in Governance Issues: Guidance Note from 1997."

${ }^{4}$ IMF Press Release n. 18/142, April 22, 2018.

${ }^{5}$ IMF, "Staff Guidance Note on the Fund's Engagement with countries in Fragile Situation", April 25, 2012 and IMF, "Staff Guidance Note on Fund Engagement with Fragile and Conflict-Affected States (FCS)", January, 2019.

"See "Use of third parties' indicators in Fund Reports", 11/2017.

4 INTERNATIONAL MONETARY FUND
}

CInternational Monetary Fund. Not for Redistribution 
international and peer country best practices and contextualized for Sudan as a fragile state to provide preliminary findings that could help inform the ongoing policy dialogue with the government. A broader and deeper IMF governance diagnostic mission has been requested by the authorities and is planned for the first half of 2020 .

\section{B. Definition of Governance, Perception and Costs of Corruption}

4. Governance, per se, is a neutral concept. While there are a range of different definitions of "governance" among IFls and academia, the IMF has provided a classification that encompasses "the various institution mechanisms and established practices through which a country exercises governmental authority, discharges its responsibility and manages its public resources", which is generally well received and accepted. ${ }^{7}$ Governance represents the manner in which power is exercised in the management of a country's resources, bridging different domains: economic, social and political. Good governance, or lack of it, deeply affects the growth, development and inclusion of a country and it has been often referred to as the single most crucial factor in the fight to eradicate poverty and promote progress. Governance is defined "good" when it respects 8 major characteristics: it is participatory; consensus oriented; accountable; transparent; responsive; effective and efficient; equitable and inclusive; and follows the rule of law.

\section{A widely accepted definition of corruption, adopted by the Fund and other IFls, is "the} abuse of public office for private gain" (IMF 2016). ${ }^{8}$ Where systemic and severe, it contributes in preventing countries from realizing their potential and achieving sustainable and inclusive growth, while favoring large income distribution disparities. It is therefore imperative for governments to understand the extent of corruption in their countries and how it affects their economic performance, so that they can determine the best strategy to fight it. It is also critical that the civil society and development partners support governments in their efforts through active participation, appropriate policy advice, technical assistance, and financial support.

\section{Weak governance and corruption, perceived or real, are often strictly linked and impose} economic costs. Corruption is often an indicator of poor governance. Moreover, in an environment characterized by weak governance, it is more difficult to effectively fight corruption. Hence, to successfully fight corruption in the long term, governance issues need to be addressed at institutional level and a "culture" of good practices needs to be established, especially in a case like Sudan where corruption is considered endemic. The existing literature highlights that inadequate governance and corruption can weaken the state's capacity to collect revenue, reduce equity and efficiency of public expenditure, discourage private investment, create inflation, and undermine trust in public institutions (IMF 2016), ultimately hampering inclusive growth. In turn, low rates of inclusive growth hinder

\footnotetext{
7 See "The Role of the Fund in Governance Issues-Review of the Guidance Note-Preliminary Considerations", 2017.

${ }^{8}$ While there are several definitions of "corruption" in use, the IMF chose in his documents this definition which focuses on the abuse by public actors and doesn't cover fraudulent acts perpetrated exclusively by private citizens. See also "The Role of the IMF in Governance Issues: Guidance Note from 1997" and in 2017 "The Role of the Fund in Governance Issues-Review of the Guidance Note-Preliminary Considerations". That said, as corruption is often facilitated or initiated by a private actor(s), any effective anti-corruption strategy needs to also address behavior within the private sector.
} 
governance advancement and can facilitate persistent or augmented levels of corruption, creating a vicious circle very difficult to break.

7. Sudan has limited institutional capacity and multiple constraints (Figure 1). Hence, it is paramount to start by rebuilding a trusted framework of good governance, reliant on transparent and accountable procedures, based on a clear communication campaign, calling on the direct involvement of the private sector and civil society as watchdog of the institutions and their functioning whenever possible. In the past years there have been a few virtuous examples of success in the fight against corruption, which hinged on the authorities seizing the opportunity of a major political change to build social consensus and make significant progress (Georgia, Rwanda, Estonia and Liberia to name a few). ${ }^{9}$ Sudan's regime change has created a window of opportunity for essential reforms and improving governance could prove fundamental in addressing major macro imbalances and revamp broad-based growth. The authorities have officially committed to engage in wide-ranging efforts to this end.

\section{Fiscal Governance}

8. Strong fiscal governance is a crucial pillar of strategic development and services delivery for governments. In view of the volume of spending it represents, governments have a fundamental responsibility to carry out Public Financial Management (PFM) and especially public procurement efficiently, ensuring high standards of conduct, adequate quality of public service delivery and costeffectiveness to safeguard the public interest. PFM, procurement, and public investment should be informed by transparency and integrity and their procedures need to be accessible, cost-effective, monitorable, subject to third party evaluation and ultimately accountable. Stakeholders and citizens should have free and easy access to all relevant documents and the applicable legislation should ensure avoidance or minimization of conflict of interests, cronyism and misallocation of resources. ${ }^{10}$

9. PFM and procurement present serious shortcomings in Sudan. The analysis of Sudan's fiscal framework highlights weaknesses in the quality and timeliness of data, lack of an organized structure of check and balance and absent or insufficient publicity of information and transparency of procedures. ${ }^{11}$ Until recently access to budgetary data has been scarce and procedures opaque. Notably, progress has lagged in incorporating a medium-term fiscal framework into budget planning and in strengthening the macro-fiscal unit to enhance policy formulation. The Single Treasury Account (TSA) needs to be fully implemented at central government level including by improving cash forecasting, extending the setting of cash ceilings for ministries, departments, and agencies from one to three months, and improving management of payments. The reports of the Auditor General had no traction or publicity despite highlighting weaknesses and inefficiencies and in some cases a series of

\footnotetext{
9 See "Fiscal Monitor: Chapter 2, Curbing Corruption", April 2019.

10 OECD, 2015. "OECD Recommendation on Public Procurement" OECD Publishing; OECD. 2017. "“OECD Recommendation on Public Integrity. A Strategy Against Corruption" OECD Publishing.

11 Kukutschka, Martinez R. B. 2017, "Sudan: Overview of Corruption and anti-corruption" U4 Anti-Corruption Resource Center, Transparency International, Berlin, and information collected during the 2020 Article IV mission.
} 


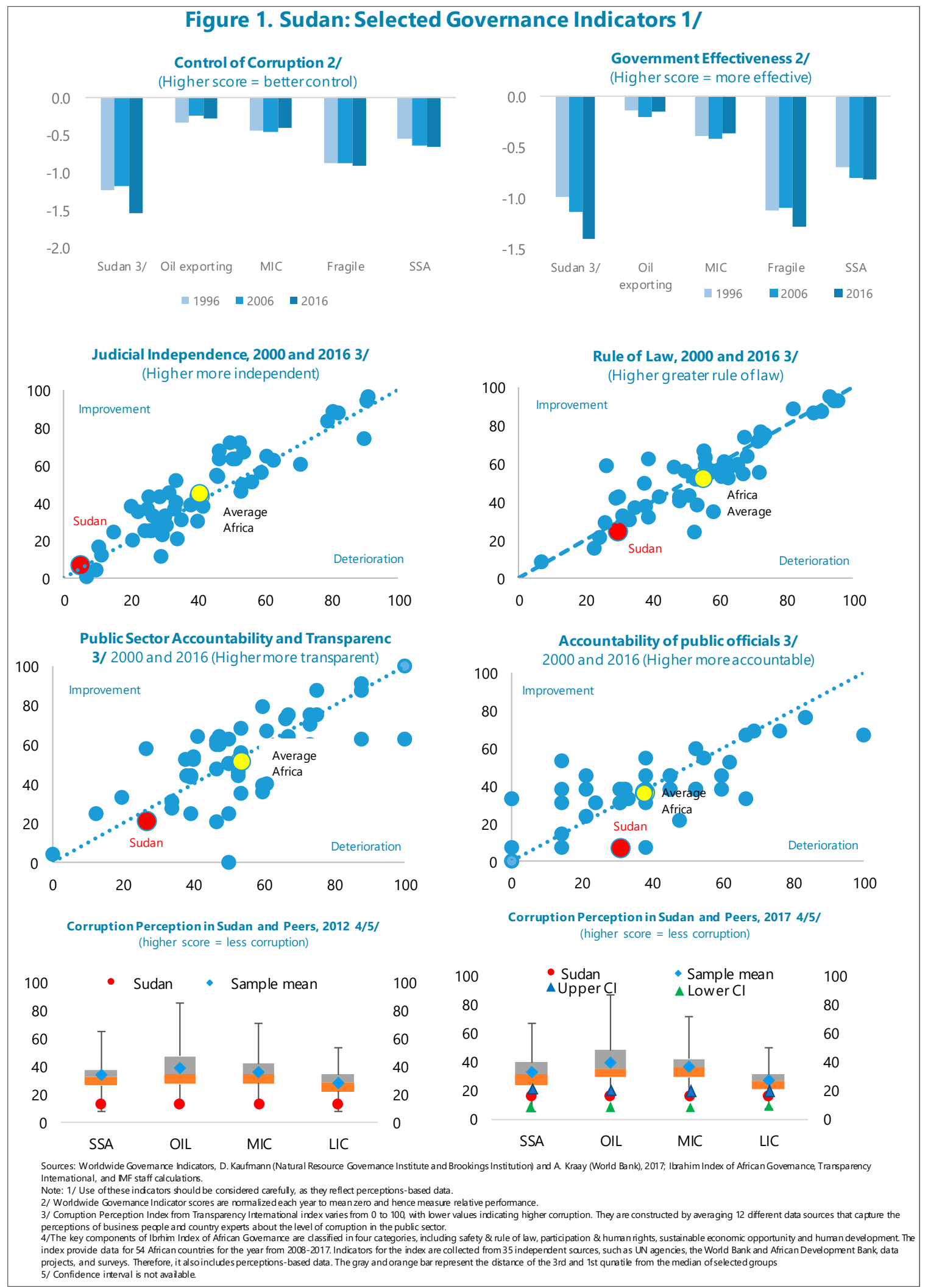

\section{CInternational Monetary Fund. Not for Redistribution}


financial irregularities. Procurement and investment activities are performed with a closed group of companies pre-identified by dedicated Units at the Ministry of Finance, and as a result, tenders are advertised without an adequate publicity mechanism that would ensure open participation. The contracts, once assigned, are monitored by the recipients of the service and it is unclear how underperformance, delays or cost overruns can be dealt with. Lack of digitalization and of an easily accessible archive system prevents any efficiency analyses and stock taking of the ongoing projects which are very scarcely monitored after the contracts are signed.

10. These governance inadequacies could be exploited to facilitate corruption which in turn further decreases the efficiency of the public system and erodes public trust. During the recent Article IV mission, the authorities announced that the procurement and investment regulation needs to be revised to incorporate international best practices and standards and lamented the difficulties faced due to lack of resources and continuous rotation of personnel which prevents them from forming long-term specialized competencies. Both the IMF and The World Bank have been providing TA on these issues and the new government has committed to address outstanding inefficiencies.

\section{A complex and opaque tax system can facilitate corruption and reduce the state's}

capacity to raise revenue. An overly complex and unaccountable tax system that grants generous tax exemptions is favor of selected business or creates "ad hoc" loopholes can be the result of a weak fiscal governance framework or the proof of a high level of corruption and "state capture". Perception of inefficiency and of corruption are very often mutually reinforced and linked but bad governance (lack of transparency, excess of regulation, lack of automated processes and of codes of conduct and so on) provides the occasion for corruption, without necessarily being the result of corruption. In either case, it encourages perceptions of corruption and create more opportunities for bribery and tax avoidance. It is proven that the perception of corruption harms the culture of compliance and increases tax evasion. Numerous and complex tax rules necessitate more frequent encounters with public officials and increase compliance costs, which also raise incentives for avoidance and corruption (Mauro 1997, Martini 2014, and IMF 2016).

\section{Sudan's tax collection is low, at about 6 percent of GDP in 2019, and far below its peers.}

(Chapter II. Revenue Mobilization). Income tax accounts for less than 10 percent of tax revenue, in part because of the historical importance of oil revenue but also because of numerous tax holidays and exemptions in the Investment Law (IMF 2017 Article IV Report) and a large informal sector (UNDP 2018 estimates it at more than 60 percent of GDP). Indirect taxes, specifically through customs, excises, and VAT, are the main sources of tax revenue, but have "too many rates" (World Bank 2014), are subject to frequent changes and deeply impacted by the multiple currency practices. As a consequence, firms in Sudan rate "customs and trade regulations" and "tax administration" as their biggest obstacles for doing business (Figure 2), ${ }^{12}$ and trading across borders is one of Sudan's worst

\footnotetext{
12 Based on Sudan Enterprise Surveys 2015, in which business owners and senior managers in 662 firms were interviewed from September 2014 through February 2015. It reflects a snapshot of the biggest business environment obstacles as perceived by firms, and the numbers indicate percent of firms surveyed that identified the obstacle as among the top 10 constraints. The survey results should be interpreted with caution owing to a limited number of respondents, a limited geographical coverage, and standardized assumptions on business constraints and information availability.
} 
performing indicators in the World Bank's Doing Business report (World Bank Group 2019). ${ }^{13}$

\section{Weak governance and corruption can also reduce the fairness and efficiency of public expenditure. The allocation of} government spending can be diverted from public services such as education, health, and sanitation in favor of large infrastructure projects and defense systems where collecting substantial bribes is easier (Delavallade 2006). Inefficient governance can weaken public service delivery and facilitate corruption which in turn by exploiting weak monitoring and accountability processes can cause large leakages in side-payments and bribes to local officials so that only a fraction of the spending reaches the intended beneficiaries (Reinikka and Svensson 2004). Lastly, as highlighted in the previous paragraph, it can reduce the efficiency of public investment through poor project selection, inadequate procurement procedures or off-budget financing, and lack of check and balances mechanisms (IMF 2016). In this respect, the large Sudanese parastatal SOE system appears particularly vulnerable to inefficiencies and abuses due to its opacity and preferential allocation of contracts. The General Auditor chamber has been very active in signaling these shortcomings with very little traction until now. The new government committed to engage in a far-reaching set of reforms and the IMF diagnostic governance mission tabled for the first half of 2020 should be of great help in prioritizing necessary measures.

\section{Sudan spends less on basic education and health than other countries in the region}

(Figure 3). Service delivery is weak, resulting in lower access to most basic services (Figure 4).

Evidence suggests that past spending on public investment has been often inefficient. A cross-country benchmarking of the efficiency of public investment using the Data Envelopment Analysis (DEA) shows that Sudan operates far from the local efficiency frontier (Figure 5). ${ }^{14}$ The analysis estimates that

13 In 2019, Sudan ranked 183 out of 189 countries and had a distance-to-frontier score of 19 out of 100 in the aggregate indicators of trading across borders (with 100 representing the best performer). The indicators of trading across borders are based on the time and costs estimates reported by local experts in practice associated with three sets of procedures-documentary compliance, border compliance and domestic transport-within the overall process of exporting or importing a shipment of goods. The results should be interpreted with caution owing to a limited number of respondents, a limited geographical coverage, and standardized assumptions on business constraints and information availability.

14 The empirical implementation of the DEA methodology in this note closely follows IMF (2015), but we update the data on both inputs and outputs to allow for data constraints in Sudan. The efficiency scores estimated here use an inputoriented DEA model, so that the estimated efficiency scores are interpreted as the proportional amount by which the country could reduce public capital inputs while producing the same level of infrastructure services. The efficiency scores are calculated relative to a peer group consisting of linear combinations of input-output observations for efficient 
peer countries operating on the efficiency frontier are producing the same level of public capital with up to 70 percent less spending. Governance shortcomings and corruption are among the potential contributing factors of inefficiency, together with lack of institutional capacity, lingering effects of the civil war, difficulties in transporting materials to remote areas, and shortages of materials and skilled professionals.
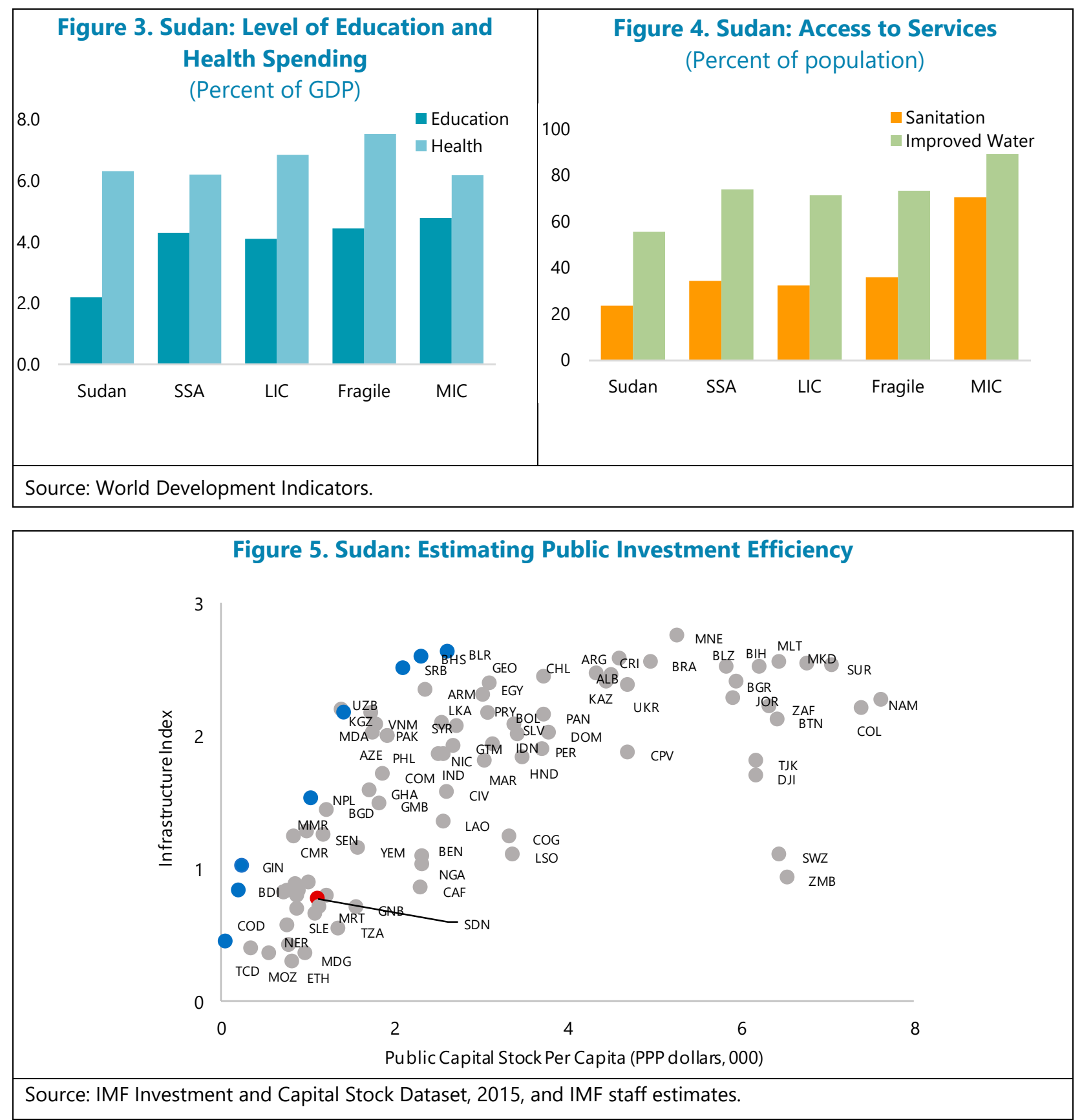

countries. Two adjustments are made so that each country is compared to others with similar characteristics. First, in addition to pubic capital, we use per capita GDP as a second input in the model. Second, instead of constant returns to scale for the model (which assumes that all countries in the sample are performing at optimal scale), we use variable returns to scale. 


\section{Financial Sector Oversight}

15. Sudan's financial sector has been subject to international sanctions since 1997. Although in 2017 the United States revoked its trade and financial sanctions, others, including Australia, Canada, the United Kingdom, the European Union, and the United Nations, kept their sanctions in place. In addition, the United States has kept Sudan on its list of state sponsors of terrorism (SSTL), which hampers negotiations of debt relief. Two decades of economic sanctions led to the exit of most correspondent banking relationships (CBRs). The sanctions continue to cost heavily in lost trade, investment, and humanitarian aid (IMF 2017). The financial system is small and financial inclusiveness is very low, especially outside of the major urban centers.

\section{Corruption can slow down a country's financial market development and increase} vulnerability to money laundering and terrorist financing. Corruption makes foreign banks reluctant to engage in business activities in a "risky" country: the probability of being sanctioned by the home supervisors for doing business with an opaque and potentially corrupt system is a very high deterrent for international credit institutions, especially in the aftermath of the global financial crisis. Weak governance, which also means supervisory forbearance and an inadequate AML/CFT framework, increases the risk of corruption and of attracting criminals and money launderers who target countries where defenses are weak. ${ }^{15}$ Moreover, corruption and lack of financial inclusiveness can create a vicious circle: an undeveloped financial system facilitates the use of cash which can more easily hide corrupt activities, while the same illicit activities slow down the financial sector development by encouraging the use of cash instead of the banking system.

17. Weak banking sector governance and regulatory/supervisory shortcomings can deeply affect the system's stability and growth, reducing the availability of credit to the economy, favoring cronyism in lending practices and the accumulation of nonperforming Loans (NPL). Sudan is a fully Islamic financial system, which makes it complex to compare international soundness indicators and supervisory rules to peers. A recent stress testing proved the system to be more fragile than showed by the previous reported data and that supervisory practices are affected by significant shortcomings, lack of capacity and continued turnover of the limited personnel which hinders the creation of necessary specialized competencies. The authorities have requested IMF TA to revise the Central Bank's Law, to strengthen its effectiveness and improve its supervisory action.

\section{E. Central Bank Governance and Operations}

18. Central Bank safeguard assessment. Since 2000, the IMF has conducted safeguard assessments on the central banks of members who have an approved Fund financial arrangement with a focus on protecting Fund resources from misuse and misreporting of program monetary data. The safeguards diagnostic evaluates the governance and control framework of a central bank in five fundamental areas: external audit, legal structure and autonomy, financial reporting and transparency, internal audit and internal controls. Assessments are usually performed before the start of a program or at its inception and completed before the first program review. As Sudan-having been in arrears with the IMF and other multilateral donors since 1984-could not receive financial support from the

15 The Economist, September 8, 2018. 
Fund since long before 2000, the Central Bank of Sudan (CBOS) has never undergone a safeguards assessment. Hence the knowledge of its governance and operations is mainly based on the evidence collected during the bilateral surveillance missions and the analysis of desk-based information.

19. Main elements of the legal framework. The Bank of Sudan Act (2002), does not stipulate operational independence, financial autonomy, accounting reporting principles and transparency, and internal and external controls. The objectives, functions and powers of the central bank are not clearly stated (Art. 6). The oversight board lacks in practice independence from the executive management as, despite part of its members being non-executive, the oversight powers can be delegated to the Chairman, who is the CBOS governor, which defies one of the basic rules of institutional governance. Moreover, the internal audit is subordinate to the Governor's office, which undermines its effectiveness and impartiality. Senior officials are appointed and removed by the Presidency and obligated to respond to the Presidency, and to act in representation of ministries and governmental institutions (lack of autonomy from political power). In the last couple of years of President's Bashir power, there was a high turnover of Governors, which de facto almost paralyzed central bank operations. There is no provision on conflict of interest or other ethics rules. The reporting framework of the CBOS is not in line with best practices and standards and the quality and timeliness of the data is poor and often difficult to reconcile across institutions.

20. Supervisory activity. The CBOS is the majority shareholder in several banks and financial institutions which creates a conflict of interest with its role as supervisor and regulator. Supervisory activities are hindered by high rotation and lack of personnel, loose application of regulations and poor quality of data from the system. The central bank law does not ban commercial banks shareholders to be appointed as executive officials, which could further impair sound supervisory practices.

21. External audit and publicity. The Central Bank Law subjects the CBOS to being audited by the General Audit Chamber, in accordance with the General Audit Chambers Act, 1999. The required standards to be followed are not mentioned, and neither is the transparency regime to be followed by the auditors. The governor of the CBOS is requested to present to the National Assembly, at the end of every year, a statement including the general policies, plans and future programs of the Central Bank, and a report on the general performance for the previous year. It is unclear whether the report should be made public and in which form. The financial statements audit of the CBOS by the National Audit Chamber are not subject to publication. A recent report by the General Auditor highlights several governance and accounting shortcomings and called for corrections including by amending the Central Bank of Sudan Law. Until recently the General Auditor's recommendations have received very little traction, as in the case of the other institutions.

22. Fiscal dominance in Sudan. On the back of a protracted economic crisis (Figure 6) and owing to the lack of autonomy of the Central Bank of Sudan and the described governance shortcomings, the government has become more reliant on seigniorage and quasi-fiscal financing (Blackburn and others 2008), with high monetization of its fiscal deficits. Fiscal dominance has weakened central bank independence and the credibility of monetary policy, increasing inflationary expectations, and has facilitated the use of multiple exchange rates. Inflation is entrenched, averaging 33 percent since the 
1970s and 23 percent in the last ten years.

Following the government's continued monetization of fiscal deficits inflation exceeded 70 percent in 2018 and is projected around 60 percent in 2019. Under the country's fixed exchange rate regime, persistently high inflation resulted in a long period of significant real exchange rate overvaluation (Figure 7), which eroded Sudan's non-resource exports competitiveness and resulted in a parallel exchange rate system.

\section{Multiple currency practices (MCP)}

persist. The government currently maintains several exchange rates, including (i) the central bank's official and commercial bank exchange rate (SDG 45/US\$); (ii) the customs exchange rate (SDG 15/US\$); (iii) the fuel import rate (SDG6.7/US\$), and (iv) the parallel market rate, at which all other transactions (about 80 percent of total) take place (around SDG 80/US\$). Moreover, the latest budget has been prepared using an exchange rate of SDG 55/US\$. The use of $\mathrm{MCP}$ raises corruption risk by encouraging rent-seeking (differential rates allow for making large profits through access to more advantageous rates) and large speculation, dragging on the economy and facilitating income polarization. Over the
Figure 6. Sudan: Macroeconomic Performance (1970-2017)

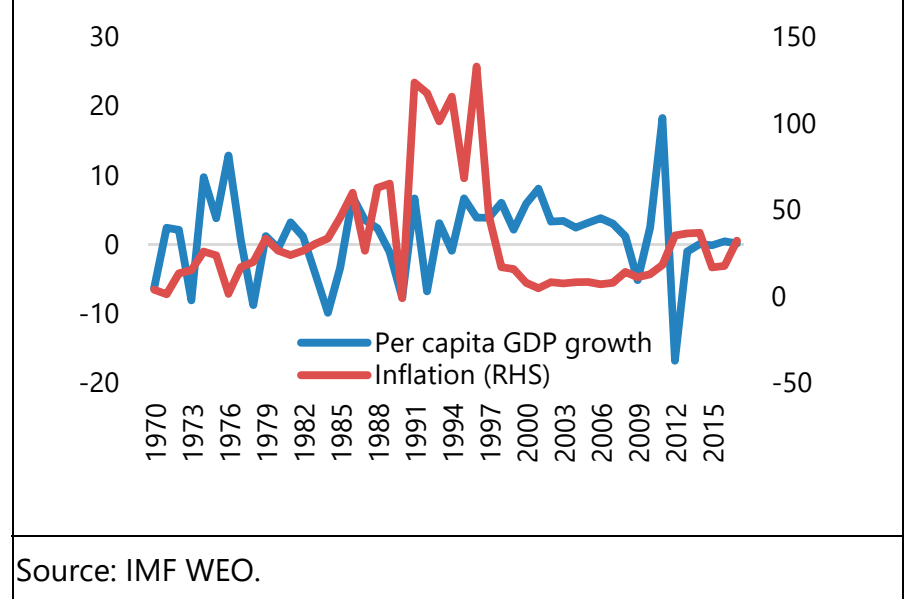

Figure 7. Sudan: Evolution of Exchange Rates in Sudan (SDG per US\$)

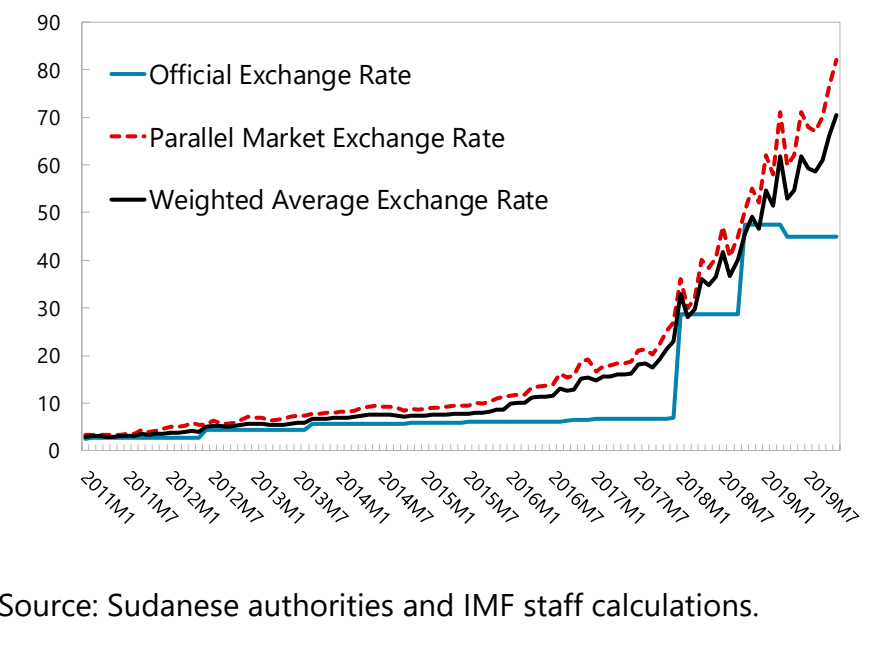
years, it has been reported that the use of MCP in Sudan has contributed to an expansion of the informal economy, smuggling of exports, loss of migrants' remittances from formal channels and exacerbated shortages of foreign exchange in the country (Ebaidalla 2015).

24. Recent developments. The authorities have indicated plans for a reform of the Central Bank Law to bring it in line with international best practices and improve the overall governance mechanism and operational activities of the CBOS. They have requested IMF support in revising the new law along these lines. 


\section{F. Market Regulation}

25. Inadequate governance and corruption can discourage private investment. Burdensome regulation and red tape create opportunities for corruption, which act as a tax on profitability (Mauro 1997). Lack of governance and appropriate check and balances on investments and expenditure coupled with a high perception of corruption may also create uncertainty about the returns to investment because of possible delays in licensing or clearance of customs, unpredictable policies, or uneven enforcement of regulation. Corruption also diverts talents from more productive activities.

\section{Sudanese businesses report corruption among their top five constraints (Figure 2).} Corruption was rated as a "major" or "very severe" constraint by 65 percent of firms-higher than the average in the region (41 percent). Concerns are greatest among smaller firms and those in the services sector (Figures 8-10). ${ }^{16}$ Within services, firms in wholesale and retail-important sectors for job creation-are more likely to report corruption as major or severe constraint. Finally, in a separate survey, a very large proportion of firms in the informal sector said corruption was their most severe constraint (World Bank 2009). These facts underscore the potential importance of corruption as an impediment to job creation in Sudan.

\section{G. Rule of Law and Anti-Corruption Enforcement}

27. The rule of law is a major principle of governance. According to it "all persons, institutions and entities, public and private, including the State itself, are accountable to laws that are publicly promulgated, equally enforced and independently adjudicated, and which are consistent with international human rights norms and standards. It requires, as well, measures to ensure adherence to the principles of supremacy of law, equality before the law, accountability to the law, fairness in the application of the law, separation of powers, participation in decision-making, legal certainty, avoidance of arbitrariness and procedural and legal transparency" ${ }^{17}$ It is considered a fundamental aspect of peacebuilding and is critical in accelerating sustainable development in LICs and fragile countries by improving safety and providing access to fair and well-functioning legal systems that adhere to international human rights standards, thus reducing or preventing violence and conflict, promoting economic investment, encouraging inclusive growth and eradicating poverty. The quality of a country's rule of law can be measured against some fundamental aspects of the institutions in charge to it: their capacity, performance, integrity, transparency and accountability.

\section{According to international agencies and existing literature, Sudan has scored very poorly on compliance with rule of law best practices in the past. Criticism has been particularly} severe with regards to the objectivity and impartiality of the judiciary and the police forces. This paper will not assess these areas, among other reasons for lack of direct information, as it was not possible

\footnotetext{
16 Based on Sudan Enterprise Surveys 2015, in which business owners and senior managers in 662 firms were interviewed from September 2014 through February 2015. The results should be interpreted with caution owing to a limited number of respondents, a limited geographical coverage, and standardized assumptions on business constraints and information availability.

17 Although the term "rule of law" is widely used, there are several definitions in literature and among different institutions. The definition used in this chapter is taken from a report to the Security Council by the United Nations Secretary-General in 2004.
} 
to gather relevant data during the latest mission. The new government is committed to enforce a fair, accountable and transparent new set of measures and actions in this sector. The forthcoming IMF macro-diagnostic governance mission requested for the first half of 2020 will be the appropriate setting for a thorough evaluation of the state of art and for providing a set of recommendations to accompany the authorities in their reform efforts.

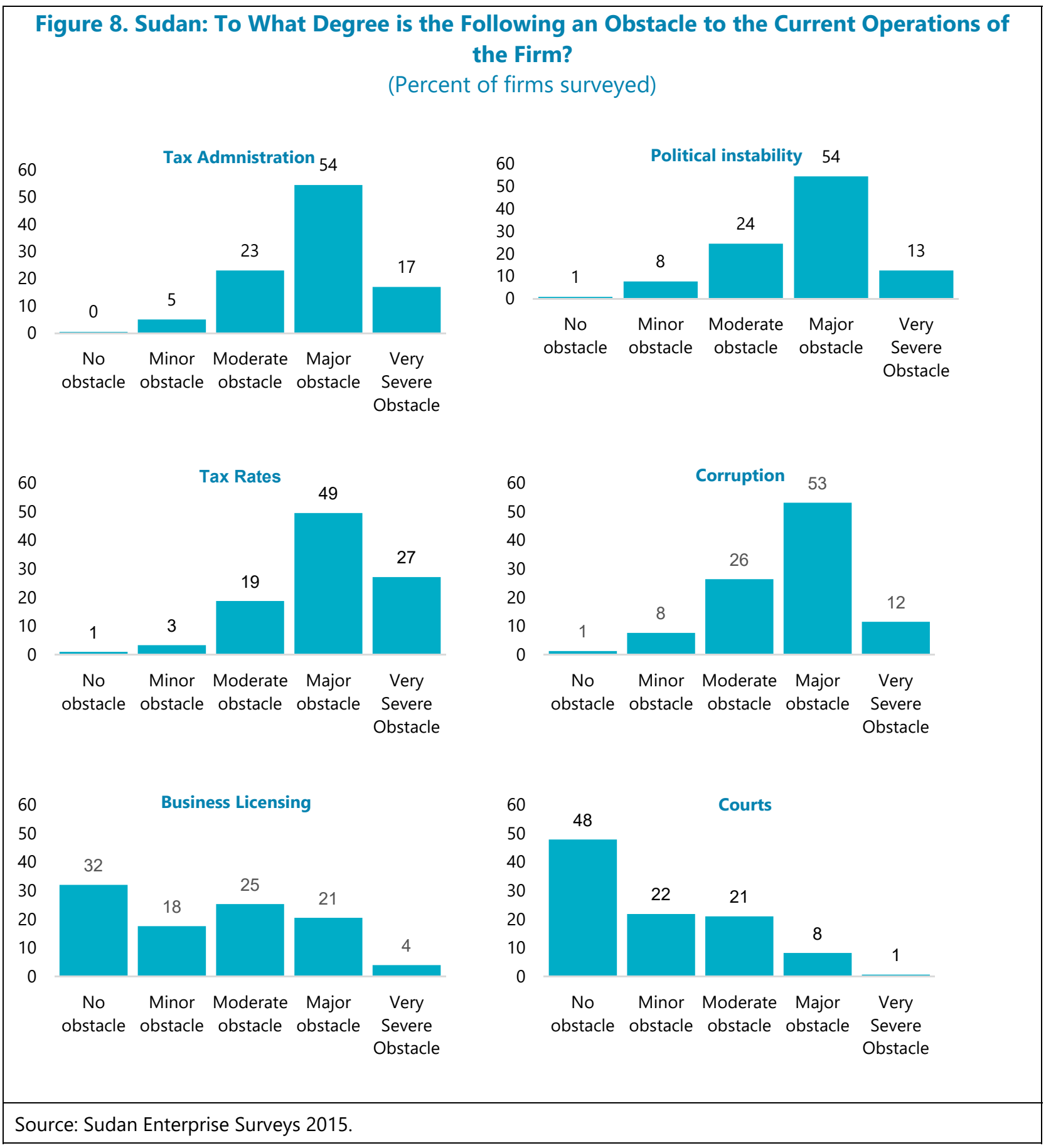




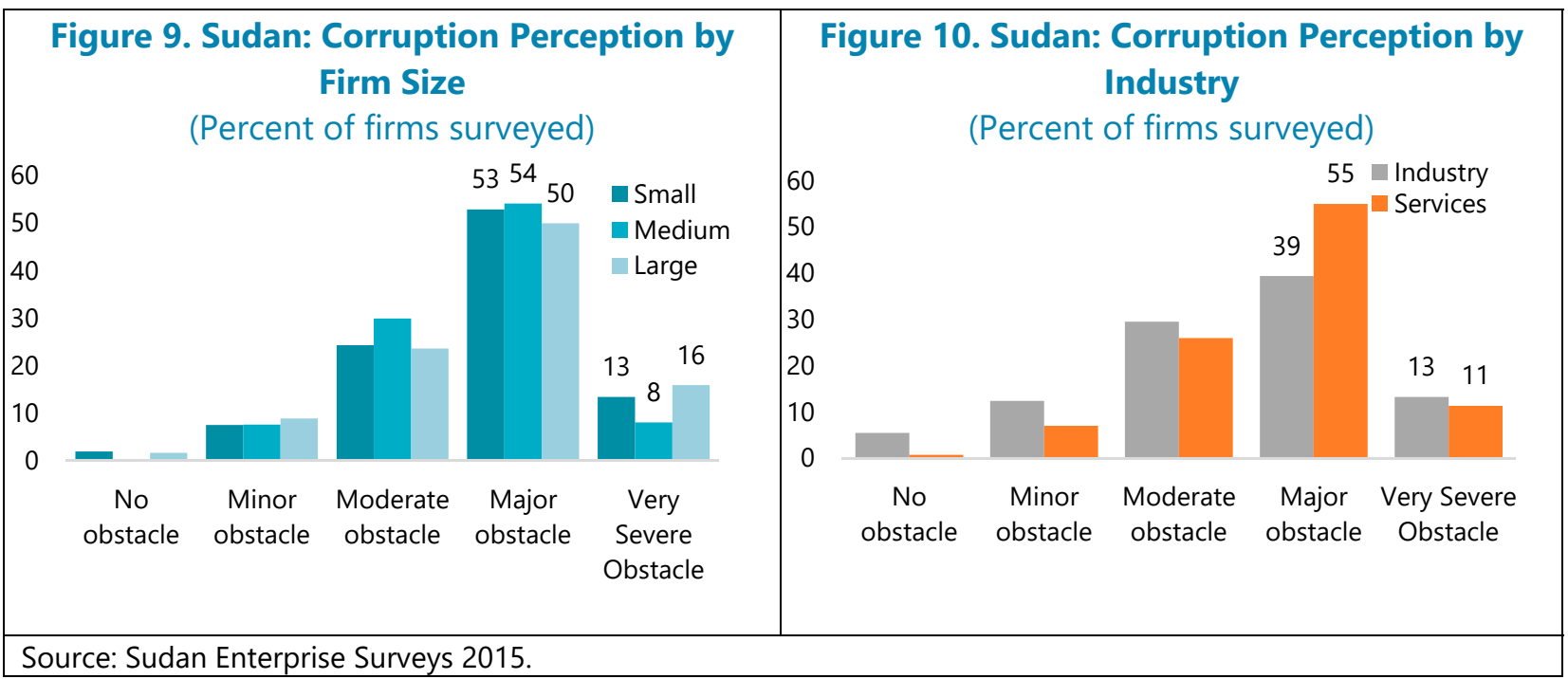

\section{H. Anti-Money Laundering and Combating the Financing of Terrorism (AML/CFT) and Anti-Corruption Framework}

\section{The AML framework includes a set of measures that can support efforts to counter corruption, such as the scrutiny of transactions of politically exposed persons (PEPs), the reporting of suspicious transactions, and criminal justice actions against proceeds of corruption and criminals.}

\section{Effective implementation of preventive measures is key, particularly in relation to} politically exposed persons (PEPs). When implementing customer due diligence (CDD), financial and non-financial institutions should identify customers, including PEPs, and apply ongoing monitoring to identify suspicious behavior. If a suspicion arises, concerned transactions should be reported to the financial intelligence unit (FIU). In Sudan, the implementation of CDD is not effective, including by nonbank institutions. The reporting of suspicious transactions is overall insufficient and limited to banks. The implementation of requirements on PEPs would be facilitated by the publication of PEP's comprehensive asset declarations. This would assist domestic banks, and financial institutions abroad to identify Sudanese politically exposed persons, compare the assets declared and the assets in their books, and report information to their respective financial intelligence units in case of unexplained discrepancy and suspicious transactions, potentially triggering prosecution of the laundering of the proceeds of acts of corruption. Such enforcement actions by foreign law enforcement agencies, could create an additional incentive for better governance in Sudan while domestic anti-corruption frameworks are being strengthened.

\section{Transparency on beneficial ownership of legal persons and arrangements to prevent} their misuse for laundering the proceeds of corruption are necessary. The 2012 FATF standards require heightened scrutiny of transactions conducted by PEPs and adequate transparency of company ownership. In Sudan, financial and non-financial institutions face challenges in obtaining adequate, accurate and current information on beneficial ownership of legal persons and arrangements, who may be PEPs. Making such information readily available through a national registry or other mechanisms covered by the FATF standards should assist domestic and foreign 
financial institutions, law enforcement agencies, journalists and civil society in identifying legal persons and arrangements connected to PEPs.

32. Effective criminal justice actions against money launderers can dissuade criminals from committing acts of corruption. In Sudan, it is not a common practice to launch parallel financial investigations of money laundering if a criminal conduct is being investigated. The number of convictions of money laundering and confiscations of proceeds of corruption, and proceeds of crime more generally, are limited. Therefore, the AML framework should be more effectively used to prosecute corruption.

\section{Concluding Remarks}

33. For a complex fragile state with limited institutional capacity such as Sudan, reforms have to be carefully calibrated and sequenced to avoid the risks of reform failure or of quick reversal. A broad approach to creating a sound and more robust governance framework, reinforcing institutional capacity and investing in human capital would be the appropriate starting point to create the environment to effectively tackle corruption. The most immediate action that should be implemented would be to increase the timeliness, quality and integrity of data and statistics, in parallel building a culture of transparency and accountability in public institutions and agencies. To avoid reform failure the civil society and private stakeholders should be actively engaged with the authorities in designing the policy strategy and the implementation plan to adopt it.

\section{Transparency, accountability and comprehensive communication should be the} backbone of governance and anti-corruption reforms in each sector. This approach should specifically include (i) significant and systemic improvements in transparency and data reporting; (ii) regulatory alignment with international best practices (through UNCAC compliance and peer review report, supervisory and accounting compliance with international standards, continued progress in the implementation of AML/CFT best practices etc.) (iii) domestic law alignment to incentivize non-corrupt behavior (such as through tax provisions) (iv) institutional enhancement (capacity development, creation of check-and-balances, better reporting and enforcement of sanctions). A culture of accountability and controls needs to be created and adequately communicated to the public to reconstruct trust in public institutions. As briefly underlined above, a big political transition like the one currently happening in Sudan represents a valuable window of opportunity to make big strides in the fight to governance abuse and corruption. It is paramount that the authorities, with the assistance of competent third parties whenever necessary, undertake a detailed and comprehensive inventory of the existing challenges preventing a smooth and effective functioning of the public institutions and accompany these efforts with continued participation of the civil society and private stakeholder to ensure sustained public support.

\section{Rationalizing tax exemptions and phasing out tax holidays would strengthen} governance while boosting fiscal revenues. Heavy corporate tax and VAT revenue losses arising from widespread tax exemptions and tax holidays can be substantially reduced by rationalizing exemptions and phasing out tax holidays, which would help reduce perceptions of corruption and tax avoidance. Reducing the number of corporate tax rates and introducing a presumptive tax for small 
businesses would further simplify and enhance the transparency of the tax system, improve compliance, and expand the tax base.

36. Customs and tax administration should be strengthened. In Sudan, firms on average make 42 payments and spend more than 23 days (180 hours) a year to comply with tax regulations (World Bank Group 2017). Reducing the number of steps needed to comply with tax regulations and investing in new technology (e.g., introducing electronic filing and payment systems) to make compliance easier would reduce opportunities for corruption, improve the business climate, and help reduce informality. These steps could be accompanied by taxpayer education, personnel training and improvements in internal control and oversight of tax collection.

37. Eliminating off-budget subsidies. A substantial portion of fuel subsidies are recorded on the central bank's balance sheet, not in the budget. Shifting these costs onto the budget and recognizing full costs of subsidies would lead to better accountability and transparency of the budget and help reduce unsustainable spending.

38. Strengthening PFM and procurement. Improving public investment management could close as much as two-thirds of the efficiency gap (IMF 2015) and reduce opportunities for corruption. Specific effective measures to improve PFM and public investment management in particular include an overall increase in transparency, including by publishing detailed information related to the complete life of the project at regular intervals and until its realization; greater use of open tenders; improving project evaluations and requiring prefeasibility studies for large projects; supporting the auditor-general's office in the assessment of the financial and legal soundness of public investment projects; and enhancing technical capacity in line ministries. The procurement process should also be redesigned and entrusted to an independent, fully staffed and highly specialized unit in charge of all the procurement process, from project design and budget allocation to final disbursement and quality controls. At this stage and given the significant shortcomings of the current system, undertaking a procurement audit could prove very effective and helpful to design measures along the all process. Full disclosure on the SOEs, their shareholders, balance sheets and interlinkages with relevant institutions should also be pursued as a priority, including to identify inefficiencies, wastefulness and redundancies.

39. Unifying multiple exchange rates. A unified market-based exchange rate would boost competitiveness and reduce rent-seeking activities, helping to establish a level playing field that would encourage investment. At the same time, assessing import duty and oil revenues at a market-determined exchange rate would generate a large revenue windfall.

40. Enforcing limits on central bank financing of the budget. Limits on central bank monetization of fiscal deficits should be reinforced to contain inflation. Relieving the central bank of responsibility for subsidies and other quasi-fiscal activities and strengthening its operational independence will improve its credibility and its capacity to deliver on the price stability mandate. 


\section{References}

Blackburn, K., K. Neanidis, and E. Haque, 2008, "Corruption, Seigniorage and Growth: Theory and Evidence," CESifo Working Paper Series No. 2354.

Ebaidalla, M., 2015, "Flow of Migrants' Remittances into Sudan: The Role of Macroeconomic Environment," Middle-East Development Journal 7 (1): 70-88.

Enterprise Surveys (http://www.enterprisesurveys.org), The World Bank.

FATF, 2012, "Corruption: A Reference Guide and Information Note on the Use of the FATF Recommendations to Support the Fight Against Corruption," The Financial Action Task Force (FATF).

Delavallade, C., 2006, Corruption and Distribution of Public Spending in Developing Countries, Journal of Economics and Finance 30 (2): 222-239.

The Economist, 2018, "Compromised Defenses: ING and Danske Bank are in the Spotlight for their Handling of Dirty Money," (September 8). The Economist. Retrieved from https://www.economist.com/printedition/2018-09-08.

International Monetary Fund, 2015a, "Making Public Investment More Efficient," Staff Report, June 2015, (Washington: International Monetary Fund).

__ 2015b, "IMF Engagement in Countries with Post-Conflict and Fragile Situations-Stocktaking." Policy Paper, June 2015, (Washington: International Monetary Fund).

_ 2016, "Corruption: Costs and Mitigating Strategies" Staff Discussion Note SDN/16/05 (Washington: International Monetary Fund).

_ 2017, "The Role of the Fund in Governance Issues-Review of the Guidance Note-Preliminary Considerations," Policy Paper, August 2017 (Washington: International Monetary Fund).

_ 2017, "Sudan 2017 Article IV Consultation," Country Report No. 17/364 (Washington: International Monetary Fund).

_ 2018, "Review of the 1997 Guidance Note on Governance-A Proposed Framework for Enhanced Fund Engagement," Staff Report, April 2018 (Washington: International Monetary Fund).

_- 2019, "Fiscal Monitor: Chapter 2, Curbing Corruption," April 2019 (Washington: International Monetary Fund).

Kaufmann, D., A. Kraay, and M. Mastruzzi, 2010, "The Worldwide Governance Indicators: Methodology and Analytical Issues." Policy Research Working Paper WPS 5430 (Washington: World Bank). 
Kukutschka, Martinez R. B., 2017, "Sudan: Overview of Corruption and Anti-corruption" U4 AntiCorruption Resource Center, Transparency International, Berlin.

Martini, 2014, "Approaches to Curbing Corruption in Tax Administration in Africa," U4 Expert Answer. Transparency International, Berlin.

Mauro, P., 1997, "Why Worry About Corruption?" Economic Issues No. 6 (Washington: International Monetary Fund).

Mungiu-Pippidi, M. and Johnston, M., 2017 "Transition to Good Governance," Cheltenham UK and Northampton USA: Edward Elgar Publishing.

Organization for Economic Cooperation and Development, 2014, "OECD Foreign Bribery Report: An Analysis of the Crime of Bribery of Foreign Public Officials," OECD Publishing.

— 2015, "OECD Recommendation on Public Procurement" OECD Publishing.

- 2017, "OECD Recommendation on Public Integrity, A Strategy Against Corruption" OECD Publishing.

Reinikka, R. and Svensson, J., 2004, "Local Capture: Evidence from a Central Government Transfer Program in Uganda," Quarterly Journal of Economics 119 (2): 679-705.

World Bank, 2009, Sudan Investment Climate Assessment (Washington: World Bank).

- 2014, "Sudan State-Level Public Expenditure Review: Meeting the Challenges of Poverty Reduction and Basic Service Delivery," Volume 2. Background Papers (Washington: World Bank).

__ 2015, "Enterprise Surveys: Sudan Country Profile 2014," Enterprise Surveys Country Profile (Washington: World Bank).

__ 2017, "Economy Profile of Sudan," Doing Business 2018 (Washington: World Bank).

United Nations Development Programme, 2018, About Sudan.

http://www.sd.undp.org/content/sudan/en/home/countryinfo.html

(CInternational Monetary Fund. Not for Redistribution 


\section{REVENUE MOBILIZATION ${ }^{1}$}

\section{A. Background and Recent Trends}

1. Tax revenue mobilization remains a key macroeconomic and developmental challenge for Sudan. A sustained and consistent increase in revenue will not only lead to direct fiscal benefits but can also contribute to social stability in both post-conflict (i.e., Sudan) and fragile states (IMF, 2017). To achieve short- to medium-term macroeconomic stability as well as overcome key longterm developmental challenges, enhancing tax collection has always been one of the central themes particularly in low-income countries (LICs). Evidence from Gaspar et al (2016) confirmed a tax "tipping point" of about 12.75 percent of GDP, beyond which tax revenue enables a significant acceleration in economic growth. ${ }^{2}$

2. As a fragile and conflict state, boosting tax revenue performance in Sudan is critical and urgent. This will create fiscal space for priority capital and social spending. It will also help mitigate the adjustment pains from reforms, the substantial reduction in donor support experienced recently and, the huge cut in oil revenue due to the secession of South Sudan. Cross-country evidence suggests scope for Sudan to double its tax revenue to levels comparable to other nonresource-rich countries.

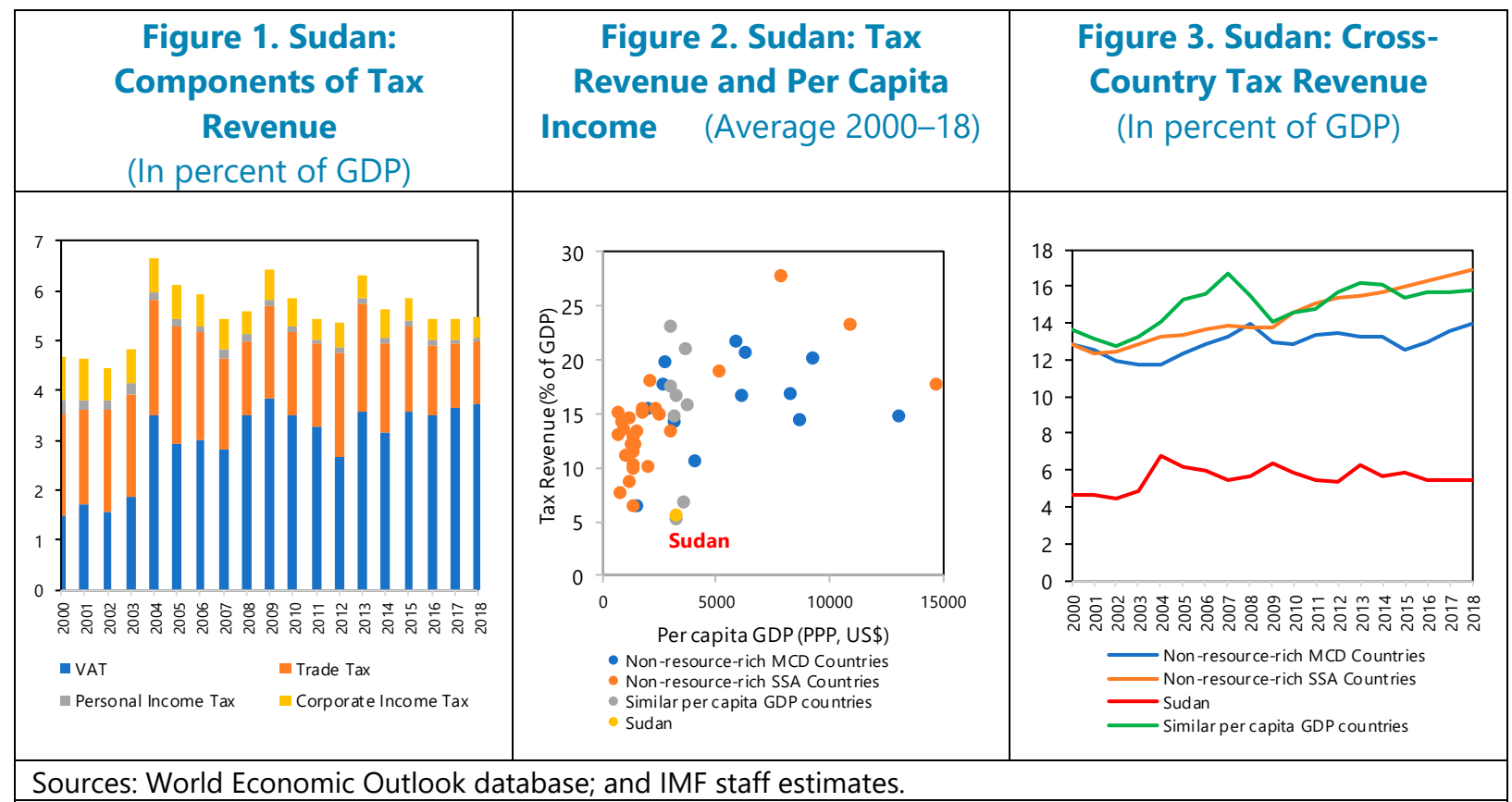

3. Sudan's tax revenue performance has been relatively stagnant over the past decade and remains significantly below potential. Total tax-to-GDP ratio in 2018 is at similar level to that

\footnotetext{
${ }^{1}$ Prepared by Olusegun Akanbi.

2 This tax tipping point has been widely accepted as the minimum threshold needed by any country and is similar to average tax revenue as percent of GDP of most LICs.
} 
in 2007 at about 5.4 percent (Figure 1). The share of income taxes (personal -PIT and corporate -CIT) and international trade taxes has continued to decline from 0.8 percent and 1.8 percent in 2007 to 0.5 percent and 1.3 percent in 2018 respectively.

4. Multiple exchange rate practices have suppressed fiscal revenues substantially. While the low tax to GDP ratio partly reflects low direct tax rates, exemptions, and weak tax administration, the significantly overvalued official exchange rate for government transactions is a major reason. Notably, import-related and oil revenues are assessed at the overvalued official exchange rate, resulting in an estimated revenue loss of about 5 percent of GDP. Significant administrative reforms at the tax and customs offices are yet to be realized despite the technical assistance (TA) delivered by the IMF and other development partners.

\section{B. Cross-Country Comparison}

\section{Tax collection in Sudan falls behind that of comparator countries and below the tax}

tipping point. The tax-to-GDP ratio in Sudan is at the bottom of countries with similar characteristics and per capita GDP (Figure 2). With broadly stable trend over the years, tax-to-GDP ratio remains far below the averages of non-resource-rich middle east and central Asia (MCD) countries, sub-Saharan Africa (SSA) countries, and countries with similar per capita income (Figure 3). Notably, Sudan has remained below the 12.75 percent of GDP "tax tipping point" identified by Gaspar et al. (2016), while other regional averages have consistently been above that threshold.

\section{The tax ratios for Sudan fall below the} average ratios of its peers in all major subcategories (Figure 4). During 2000-18, Sudan's PIT has averaged 0.14 percent of GDP-the lowest among comparators, and far below the level of 2.6 percent of GDP of non-resource-rich MCD and SSA countries. A similar trend occurred with CIT which amounted to 0.6 percent of GDP, compared to 2.8 percent. For the same period, VAT collection in Sudan also remained at a low level of about 3 percent of GDP. This is below the average of other MCD and SSA by about 4 percent of GDP. Taxes on international trade-with almost 100 percent exemptions from export taxes-amounted to 1.9 percent of GDP compared to 3.2 percent in the comparator countries.

\begin{tabular}{|c|c|c|c|}
\hline & $\begin{array}{l}\text { Corporate } \\
\text { Income Tax }\end{array}$ & $\begin{array}{c}\text { Personal } \\
\text { Income Tax }\end{array}$ & $\begin{array}{c}\text { Value } \\
\text { Added Tax }\end{array}$ \\
\hline & & (In percent) & \\
\hline Benin & 30 & 45 & 18 \\
\hline Cabo Verde & 25 & 20 & 15 \\
\hline Central African Republic & 30 & 40 & 19 \\
\hline Djibouti & 25 & 30 & 10 \\
\hline Eritrea & 34 & 30 & -- \\
\hline Gambia, The & 31 & 30 & 15 \\
\hline Georgia & 15 & 20 & 18 \\
\hline Ghana & 25 & 25 & 15 \\
\hline Guinea-Bissau & 25 & 12 & -- \\
\hline Jordan & 20 & 20 & 16 \\
\hline Kyrgyz Republic & 10 & 10 & 0 \\
\hline Mauritius & 15 & 15 & 15 \\
\hline Morocco & 30 & 38 & 20 \\
\hline Namibia & 33 & 37 & 15 \\
\hline São Tomé and Príncipe & 25 & 25 & -- \\
\hline Sudan & 10 & 15 & 17 \\
\hline Tajikistan & 24 & 13 & 18 \\
\hline Togo & 29 & 35 & 18 \\
\hline Uganda & 30 & 40 & 18 \\
\hline Zimbabwe & 25 & 50 & 15 \\
\hline Average & 25 & 28 & 15 \\
\hline
\end{tabular}

Sources: Fiscal Affairs Department (Tax Rates Database), IMF. 1/ PIT and CIT rates are for the top income bracket. 
7. Tax rates in Sudan are generally on the low side among its comparators (Table 1). CIT and PIT rates in Sudan are among the lowest in the non-resource-rich MCD and SSA countries, and, uniquely, below the region's averages. While Sudan's VAT rates are comparable and in line with international standards, CIT and PIT rates are not comparable to rates prevailing in most comparator's countries.

Figure 4. Sudan: Cross-Country Comparison of Sudan's Tax Revenue Performance, 2000-18
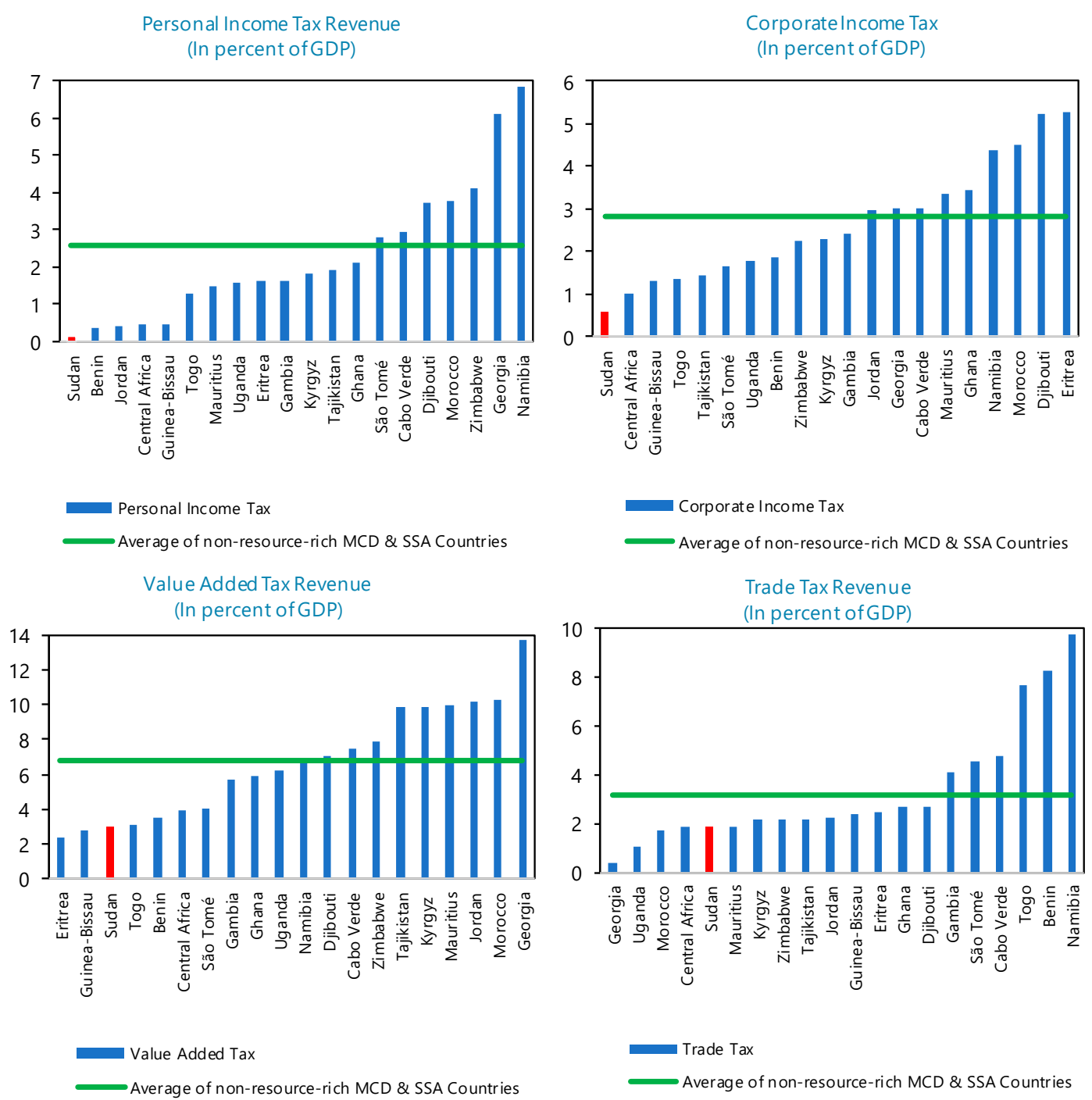

Source: World Economic Outlook database; and IMF staff estimates.

C. Successful Country Experiences in Mobilizing Tax Revenue

8. Many fragile states and low-income countries (LICs) have significantly increased tax revenue collection over a medium-term period. As highlighted in Akitoby et al (2018), several fragile states and LICs have sustained increases in their tax-to-GDP ratios, even under unstable 
economic and political conditions. These have been achieved through a combination of improved revenue administration (i.e. modernizing tax administration, improving tax compliance and combating tax evasion and corruption) and tax policy reforms (i.e. removing huge tax exemptions, changing tax rates and broadening the tax base). Liberia and Burkina Faso are good case studies that have managed to increase tax-to-GDP ratios by at least 5 percentage points between 2008 and 2012.

\section{How Can Sudan Mobilize More Tax Revenue?}

9. Improving tax performance in Sudan will entail overcoming many obstacles. Sudan will have to embark on a combination of tax policy and administrative reforms to overcome weak administrative capacity, generous tax exemptions, poor tax compliance and limited skilled human resources. Removal of all tax exemptions is urgent and should be one of the first policy action of the authorities.

10. There is a need to increase the tax base and eliminate the huge exemptions on some sectors and population groups (Table 2). The current PIT scheme indicates that 85 percent of public employees are exempted from paying taxes given that most employees earn below the taxfree threshold and are in the agricultural sector. Moreover, tax brackets are narrow, and the 15 percent highest PIT rate does not indicate a progressive tax system. Staff proposed a more progressive PIT system which broadens the tax brackets and makes top income earners pay higher tax rates of 30 percent.

\section{Steps to remove PIT exemptions could broaden the tax base by an additional $\mathbf{5 5}$} percent or more. Only 15 percent of employees are captured in the current PIT system. About 55 percent (income from agricultural sector and public employees age 50 years and above) of total employees are exempted from PIT. This figure may be higher if income earners below the tax threshold and others in the informal sector could be quantified.

\begin{tabular}{|c|c|c|c|c|c|}
\hline Table 2. Sudan: & \multicolumn{4}{|c|}{ Current PIT Scheme } & ons \\
\hline Income group (SDG) & $\leq 9,009$ & $9,010-9,129$ & $9,130-9,399$ & $>9,400$ & \\
\hline Tax rate $(\%)$ & 0 & 5 & 10 & 15 & \\
\hline \multicolumn{6}{|c|}{ Proposed PIT Scheme } \\
\hline Income group (SDG) & $\leq 7,500$ & $7,500-10,000$ & $10,000-20,000$ & $20,000-50,000$ & $>50,000$ \\
\hline Rate (\%) & 0 & 5 & 10 & 20 & 30 \\
\hline \multicolumn{6}{|c|}{ Indicative PIT Exemptions } \\
\hline & $\begin{array}{l}\text { Agricultural } \\
\text { sector }\end{array}$ & $\begin{array}{c}\text { Age } 50 \text { years } \\
\& \text { above }\end{array}$ & $\begin{array}{l}\text { Below tax } \\
\text { threshold }\end{array}$ & $\begin{array}{c}\text { Total tax } \\
\text { payers }\end{array}$ & \\
\hline Employees' population (\%) & 46 & 9 & 30 & 15 & \\
\hline \multicolumn{6}{|c|}{ Current CIT Scheme } \\
\hline & $\begin{array}{l}\text { Agricultural } \\
\text { activities }\end{array}$ & $\begin{array}{l}\text { Industrial } \\
\text { activities }\end{array}$ & $\begin{array}{c}\text { Commercial \& } \\
\text { service activities }\end{array}$ & $\begin{array}{l}\text { Tobacco \& } \\
\text { mining } \\
\text { companies }\end{array}$ & $\begin{array}{l}\text { Oil \& gas } \\
\text { activities }\end{array}$ \\
\hline Tax rate (\%) & 0 & 10 & 15 & 30 & 35 \\
\hline
\end{tabular}


12. Corporate income tax yields could be increased through unification of the tax rates and broadening of the tax base. Staff have recommended a unification of the 5 CIT rates to at least 15 percent and that all agricultural activities should be included in the tax system. Like PIT, 15 percent CIT tax rate on agricultural activities could boost CIT revenue significantly. Agriculture represents about 31 percent of GDP but does not contribute any CIT, which is likely to promote rent-seeking behavior which creates corruption and weaker governance.

13. Eliminating the huge exemptions on international trade taxes could boost tax revenue by an additional 1.2 percent of GDP. Based on Sudan customs' monthly financial performance report 2017, revenue loss of imports tax exempted from customs duty amounted to about 43 percent of import duty collected while revenue loss of imported value added tax (VAT) is recorded to be 37 percent of imported VAT collected (Table 3). Exemptions from investment law and financial sector are the largest with about 32.7 percent and 22 percent loss in revenue respectively. Authorities will need to focus on the full implementation of a risk management function and the control of the free zones to limit potential revenue leakages.

\begin{tabular}{lcc|}
\hline \multicolumn{3}{c}{ Table 3. Sudan: Exemptions from Customs Duty and VAT Imports } \\
\hline \multicolumn{2}{c}{ Type of exemption } & \multicolumn{2}{c|}{ Percent loss in revenue: Ratio of total collection } \\
\cline { 2 - 3 } Imports by investment law & 33 & 9.5 \\
Imports by COMESA agreement & 4.4 & - \\
Imports of diplomatic corps & 1.7 & 1.6 \\
Exemption under article 54 & 1.9 & 2.2 \\
Exemption under article 186 & 0.6 & 0.4 \\
Arab zone & 0.3 & 0.0 \\
Financial & - & 22 \\
Bilateral: Sudan \& Ethiopia & 1.0 & - \\
Other & 0.4 & 1.1 \\
\hline Total revenue loss & $\mathbf{4 3}$ & $\mathbf{3 7}$ \\
\hline Sources: Sudan's customs authority and IMF staff estimates. & \\
\hline
\end{tabular}

\section{Exchange rate liberalization and stronger tax administrative capacity will boost tax} revenue and give room for more social spending to cushion the pain of reform. Staff estimate that with the full liberalization of the exchange rate, import-related tax revenue will be boosted by at least 3.2 percent of GDP. ${ }^{3}$ This will be achieved alongside with strengthening of tax administration and improved compliance. Given the weak tax administration and compliance, import-related tax revenue remains subdued in 2018 -with a decline of about 0.02 percent of GDP- despite a

\footnotetext{
${ }^{3}$ An additional 1.8 percent of GDP is also expected from oil-related revenue when exchange rate is fully liberalized.
} 
168 percent (from SDG 6.67 to SDG 18 per US\$ to SDG 45 per US\$) devaluation of the exchange rate at the beginning and last quarter of 2018. ${ }^{4}$ To strengthen tax administration, it is important to focus on taxpayer segmentation that identify and address compliance risk especially for large and medium taxpayers.

\section{E. Conclusions}

\section{This analysis shows that Sudan is behind its comparators in tax revenue mobilization} and that there is substantial opportunity to raise tax revenue. Tax revenue in Sudan is below comparator countries due to inadequacies and weaknesses in tax administration and policy existing over the past decades. Given the huge cut in oil revenue and declining donor support, the government of Sudan is faced with a new challenge of mobilizing tax revenue to support investment and other priority spending. Tax revenue collection needs to rapidly increase to the level of its comparator countries. Countries with similar economic and political circumstances like Sudan have been able to achieve significant increase in their tax revenue performance over the medium-term. To attain a target of about 13 percent tax-to-GDP ratio in Sudan may take more than a mediumterm horizon but a steadfast improvement in tax policy alone could achieve about 50 percent of this target over the short-term.

\footnotetext{
${ }^{4}$ Additional revenue from oil of about 0.5 percent of GDP was realized in 2018 mainly due to exchange rate devaluation and increases in crude oil prices. This was valued at SDG 18 per US\$.
} 


\section{References}

Akitoby, B., A. Baum, C. Hackney, O. Harrison, K. Primus, and V. Salins, (2018), "Large Tax Revenue Mobilization Episodes in Emerging Markets Low-Income Countries: Lessons from a New Dataset", IMF Working Paper 18/234 (Washington: International Monetary Fund).

Gaspar, V., L. Jaramillo, and P. Wingender, 2016, "Tax Capacity and Growth: Is there a Tipping Point?" IMF Working Paper No. 16/234 (Washington: International Monetary Fund).

International Monetary Fund, 2017, "Building Fiscal Capacity in Fragile Space," IMF Policy Paper (Washington: International Monetary Fund).

__ 2013, "Tax Reform Strategy for Revenue Mobilization," IMF Technical Assistance Report by Peter Mullins, Dora Benedek, and Ashraf Al Arabi (Washington: International Monetary Fund). 


\section{SUDAN'S OIL SECTOR: HISTORY, POLICIES, AND OUTLOOK $^{1}$}

The oil sector has played a crucial role in Sudan's politics and economy, but Sudan lost 75 percent of crude oil production after the secession of South Sudan in 2012. Recent policies have focused on facilitating ballooning fuel subsidies that have intensified a vicious cycle of inflation and exchange rate depreciation, and also damaged the outlook for the sector. This paper reviews oil sector developments, discusses challenges faced by the sector, and provides preliminary recommendations for continued development in the oil industry.

\section{A. The Booming Oil Sector Before the Secession of South Sudan}

1. Foreign companies have dominated in the development of Sudan's oil sector. U.S. oil giant Chevron, as the first foreign company to invest in the oil sector in Sudan, conducted extensive onshore exploration activities from 1974 onward, mapping out the Muglad and Melut basins, with major discoveries at Bentiu (later renamed Unity), Heglig and Adar Yale oil fields. However, due to the second civil war in 1984, Chevron suspended its operations and was forced to pull out from Sudan in 1992 following increased political uncertainty and pressure from the U.S. government. The deteriorating relationship between Khartoum and Washington, especially the U.S. sanctions against Sudan, also made other big oil companies shun Sudan, while several small oil companies stepped into the vacuum and continued to explore and build operational infrastructure for a few years before Asian companies entered the Sudanese oil market. Asian companies, including China National Petroleum Corporation (CNPC), Malaysia state-owned company, Petronas, Indian Oil and Natural Gas Company (ONGC) (Table1), have dominated Sudan's oil market since $1995 .{ }^{2}$ On August 31,1999 , the first 1500 barrels of crude oil were exported to the international market.

2. Oil wealth surged with new oil fields and high international oil prices. Oil production grew rapidly, especially after the end of the second civil war in 2005, from 305,000 barrels per day (bpd) in 2005 to the peak of 483,000 bpd in 2007 and stayed around 460,000 bpd till 2010. Sudan therefore became the third largest African oil exporter after Nigeria and Angola. In the early 2000s, rising international oil prices also boosted oil exports, which increased by 30 percent per year on average while the share of oil in exports increased from 36 percent in 1999 to 95 percent in 2008, with gross foreign reserves rising to US\$12 billion in 2011. The booming oil sector also contributed to steady economic growth averaging 6 percent in this period. Fiscal revenue doubled from 7.6 percent of GDP to 15.2 percent of GDP between 1999 and 2011 as oil revenue contributed to 60 percent of the total revenue.

\footnotetext{
1 Prepared by Qiaoe Chen.

${ }^{2}$ CNPC, Petronas and ONGC are the main foreign players in South Sudan's oil market as well.
} 


\begin{tabular}{|c|c|c|c|}
\hline \multicolumn{4}{|c|}{ Table 1. Sudan: Main Oil Companies in Sudan } \\
\hline Consortium/Subsidiary & Shareholders & Share (\%) & Country of Origin \\
\hline \multirow{4}{*}{ Greater Nile Petroleum Operating Company (GNPOC) } & CNPC & 40 & China \\
\hline & Petronas & 30 & Malaysia \\
\hline & ONGC & 25 & India \\
\hline & Sudapet & 5 & Sudan \\
\hline \multirow{2}{*}{ Petro Enegry E\&P (PEOC) } & CNPC & 95 & China \\
\hline & Sudapet & 5 & Sudan \\
\hline \multirow{5}{*}{ Petrodar Operating Company } & CNPC & 41 & China \\
\hline & Petronas & 40 & Malaysia \\
\hline & Sudapet & 8 & Sudan \\
\hline & SINOPEC & 6 & China \\
\hline & Tri-Ocean Energy & 5 & Egypt \\
\hline Petrolines for Crude Oil Ltd (PETCO) & & 100 & Sudan \\
\hline
\end{tabular}

\section{Sudan developed refinery capacity to extend its value chain. In 1996, CNPC and} Sudanese Petroleum Corporation (SPC) jointly built the Khartoum Refinery Co. Ltd (KRC) to produce fuel products domestically. With the rapid growth of crude oil production, refinery capacity was expanded to 100,000 bpd in 2006. The KRC also built the world first delayed coking unit (DCU) to process heavy Fula oil (maximum refining capacity of 40,000 bpd), which is highly acid crude oil (measured by the total acid number, or TAN) and needs special methods to reduce the risks of corrosion. Later, CNPC also built Port Sudan Refinery (currently out of service due to high cost of its modernization). In addition, Sudan has three other small refining plants, namely El-Obeid, Shajirah, Abu Gabra, but only El-Obeid is active with a capacity of 10,000 bpd of Nile blend, and produces gasoline, diesel and fuel oil for electricity generation. In 2019, CNPC reduced its ownership from 50 percent to 10 percent.

\section{Oil pipelines were built to bring oil from the south to the northern port for export.}

Two pipelines are currently running from the oil fields in the south to the Bashayer Marine Terminal in Port of Sudan or to oil refineries in Khartoum. The first, Great Nile oil pipeline (1600 km), built in 1999, transports Nile blend crude oil from the Heglig oil fields (Blocks 2 and 4) in Sudan and the Thar Jath and Mala oil fields in South Sudan to the Bashayer Marine Terminal for export and to two refineries in El-Obeid and Khartoum. The second, the Petrodar (PDOC) pipeline $(1380 \mathrm{~km})$, transports crude oil from Palogue and Adar Yale oil fields in the Melut Basin to the Bashayer Marine Terminal. The two pipelines could transport 1.5 million barrels of crude oil per day. In September 2014 , ownership of the pipelines and facilities was fully transferred from joint ventures to a local Sudanese pipeline operator, Petrolines.

\section{However, oil wealth is now close to depletion after the secession of South Sudan in} 2012. Because most oil blocks are in the territory of South Sudan, Sudan's oil production capacity reduced substantially after the secession. In addition, existing oil fields are nearing depletion. Thus, 
crude oil production has dropped from about 130,000 bpd in 2013 to about 72,000 bpd in 2019 (Figure 1). According to BP Statistical Review of World Energy for 2019, Sudan's proven oil reserves at end-2018 are at 1500 million barrels only, with a low recovery to production ratio of 41.1 .

\section{An Oil Agreement between Sudan and South Sudan was signed as one component of the secession} agreement. South Sudan voted to separate from Sudan in 2011 after the Comprehensive Peace Agreement (CPA) signed in 2005. With international community mediation, the two parties separated according to a series of cooperation agreements, including an Oil Agreement, which stipulates how to share the oil facilities and use of the pipelines. The Government of South Sudan would pay US $\$ 3.028$ billion under the Temporary Financial Arrangement (TFA) to the Government of Sudan for the oil field infrastructure over 3.5 years, or US $\$ 15$ per barrel of oil produced in South Sudan, until the total amount would be paid. South Sudan would also pay Sudan US\$11 per barrel for crude produced in block 1, 2, and 4 in South Sudan, including oil processing fees (US\$1.6 per barrel), transportation fees (US\$8.4 per barrel), and transit fees to the sovereign (US\$1.0). In addition, crude oil from blocks 3 and 7 in South Sudan will pay oil transit fees (US\$9.1 per barrel) for oil transported through the pipeline in the territory of Sudan. ${ }^{3}$ The Oil Agreement has been extended several times since then. As at end-2019, South Sudan still owns US\$574 million in TFA payment to Sudan.

\section{B. Complex Opaque Financial Flows, Weak Governance, and Large Subsidies}

\section{The oil sector faces significant challenges in addition to the dwindling reserves.}

Production could be increased to more than 100,000 bpd easily by investing in primary recovery techniques according to an expert assessment. ${ }^{4}$ However, all foreign investors, except CNPC, chose to leave Sudan by 2020 after their contracts terminated. No new foreign investors expressed interest in exploring this market when the authorities offered 15 blocks to international investors after the United States lifted economic sanctions in 2017. While the lack of interest could reflect low expectations of large new oil finds in Sudan, it also appears to reflect governance and policy

\footnotetext{
${ }^{3}$ Both GNPOC and Petrodar are headquartered in Khartoum. GNPOC installed oil production and processing facilities for 5 oil fields in the Muglad Basin of South Sudan. Petrodar has facilities in the oil field of Melut Basin in South Sudan. According to the Oil Agreement, South Sudan would pay for use of these facilities.

${ }^{4}$ https://www.energyvoice.com/oilandgas/africa/212806/technology-and-tribulations-in-sudan/
} 
weaknesses. Without foreign investment, the Government of Sudan has been unable to develop this sector due to resource constraint and lack of a clear development strategy. Notably:

- The State-Owned Enterprises (SOEs) in the oil sector are not operated on a commercial basis. SOEs now dominate the oil sector, including Sudan National Petroleum Corporation (Sudapet), SPC and KRC, but none of them are run on a market basis. Sudapet is reportedly not active in oil exploration, but only manages revenues the government receives from the profit-sharing agreement (PSA) with foreign partners. SPC used to be responsible for import and distribution of fuels, but it was dissolved in March 2019 by order of the Prime Minister with no reasons published, and all assets and employees were transferred to the Ministry of Energy and Mining (MOEM). KRC also operates on non-commercial basis: it only processes crude oil delivered by the government and hands the final products back to the government. As a result, these SOEs have no incentives to further invest to improve production or reduce costs.

- The MOEM is heavily involved in the oil business. It regulates the oil sector and also manages the financial operations of SOEs in the sector. As regulator, the MOEM is responsible for establishing the sector's development strategy, cooperating with foreign investors, and administrating domestic fuel markets. It also manages the above-mentioned SOEs, including their production, imports and sales of fuel products to distributers in the retail market, and pays taxes to the government. Since many financial transactions are charged by MOEM internally, the SOE's financial situation is not transparent to the public, and there is a potential conflict of interest between the government and SOEs.

- Rising energy subsidies have dried up government resources and triggered a vicious cycle of inflation and exchange rate depreciation in the economy. With limited access to external financing and the limited domestic securities market, monetization by the Central Bank has become the principal channel for financing government deficits. Moreover, the energy subsidies have forced to central bank to engage in a variety of quasifiscal operations to acquire forex to support government import of strategic goodsincluding fuel, medicine, and wheat. ${ }^{5}$ These actions have undermined central bank independence and led to very rapid reserve money growth, high inflation, and currency depreciation (Figure 2).

Figure 2. Sudan: Inflation, Exchange Rate and Fuel Subsidies

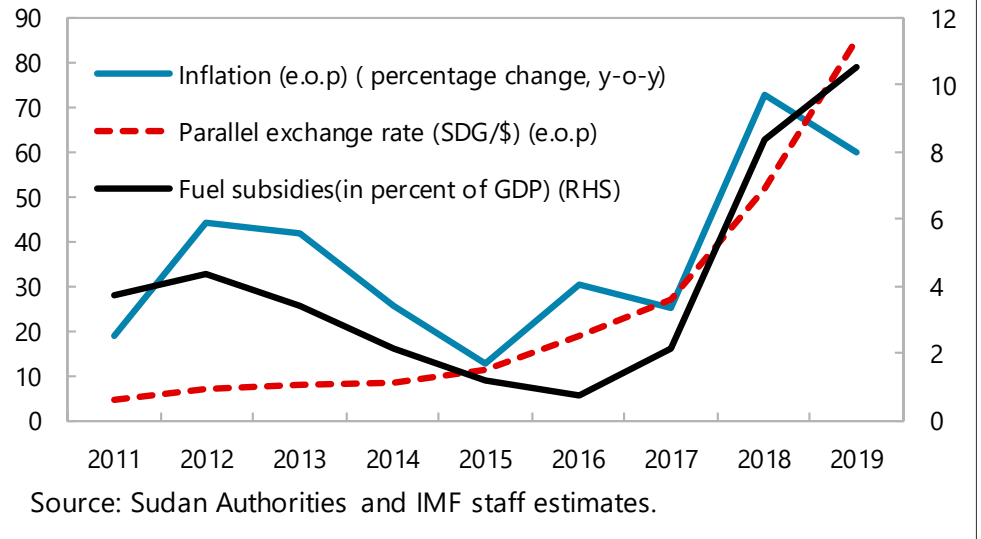

\footnotetext{
${ }^{5}$ Sudan implemented multiple exchange rates to serve different purposes. For example, government uses lower than the official exchange rate to import strategic goods, including fuel, medicine and wheat.
} 
8. Domestic fuel prices in Sudan are among the lowest in the world (Figure 3 ). Prices of gasoline, diesel, fuel oil/heavy fuel oil, kerosene and liquified petroleum gas (LPG) are all administrated by government and are far below the cost of production/import. For example, gasoline is priced at US\$0.14 per liter while diesel is at US $\$ 0.09$ per

\begin{tabular}{|lcccc|}
\hline \multicolumn{5}{|c|}{ Figure 3. Sudan: Gap Between Domestic and International Fuel Prices } \\
\hline Fuel type & $\begin{array}{c}\text { Current } \\
\text { domestic } \\
\text { prices } \\
\text { (SDG/litre) }\end{array}$ & $\begin{array}{c}\text { Current } \\
\text { international } \\
\text { prices } \\
\text { (SDG/litre) }\end{array}$ & $\begin{array}{c}\text { Price } \\
\text { increase } \\
\text { (percent) }\end{array}$ & $\begin{array}{c}\text { Share in total } \\
\text { consumption (percent) }\end{array}$ \\
\hline Gasoline & 6.4 & 44.6 & 601 & 24.9 \\
Diesel & 4.3 & 43.6 & 910 & 54.7 \\
Fuel oil & 4.3 & 32.5 & 665 & 5.2 \\
Kerosene & 4.1 & 40.1 & 876 & 0.2 \\
LPG & 5.2 & 24.9 & 380 & 12.7 \\
\hline 1/ Evaluated at exchange rate of SDG 82/US\$. & \multicolumn{4}{c}{} \\
\hline \multicolumn{5}{|c}{} \\
\hline
\end{tabular}
liter, among the lowest in the world. ${ }^{6}$ Gasoline is used mainly by private vehicles, diesel is for public transportation and agricultural activities, fuel oil for electricity generation, and kerosene and LPG for household cooking.

\section{Fuels importing needs increased since domestic production could not meet demands.}

Sudan used to only import 50 percent of diesel and 15 percent of LPG consumed in the domestic market and export a small amount of gasoline. However, fuel import needs increased once domestic refineries could not run on full capacity due to reductions in crude oil production. Particularly after 2016, the share of domestic production in total consumption dropped significantly, with 50 percent of gasoline, more than 60 percent of diesel, and 50 percent of LPG needing to be imported in 2019. Moreover, the MOEM also paid very high credit premiums to import fuels because it had to delay payments when the Central Bank struggled to allocate limited foreign exchange.

\section{The MOFEP has had to make various efforts to supply crude oil for the domestic} refineries. To maintain the proper operation of the refineries, they must process at about 80 percent or more of its full capacity, or $77,000 \mathrm{bpd}$ of crude oil. With the government share of crude oils dropping to close to $40,000 \mathrm{bpd}$, it had to seek crude oil from other sources, including purchases from foreign partners and converting payments of South Sudan under the Oil Agreement into crude oil transported in the Sudanese pipelines (14,000 bpd in 2019 was diverted to the refineries).

11. Multiple exchange rates have been used by oil sector companies. For example, domestic refineries use exchange rate of SDG 18/US\$ to convert the cost of crude oil (which is in line with international market price) to calculate the processing fees that are used to measure the cost of domestic production (US\$6.99 per barrel in 2018 and 2019 and US\$4.42 in 2016 and 2017), and SDG 45/US\$ for importing of other materials. Government has paid foreign partners for their crude oil in domestic currency by using exchange rate of SDG 26/US\$ and purchased foreign exchange from central Bank at exchange rate of SDG 18/US\$, while the Central Bank's cost of obtaining

\footnotetext{
${ }^{6}$ Daily prices are tracked by Globalpetrolprices.com at https://www.globalpetrolprices.com/. In Sudan, the last domestic fuel prices increase was in end-2016.
} 
foreign exchange from domestic gold miners is at parallel market exchange rate (about SDG 85/US\$ in December 2019) (Figure 4).

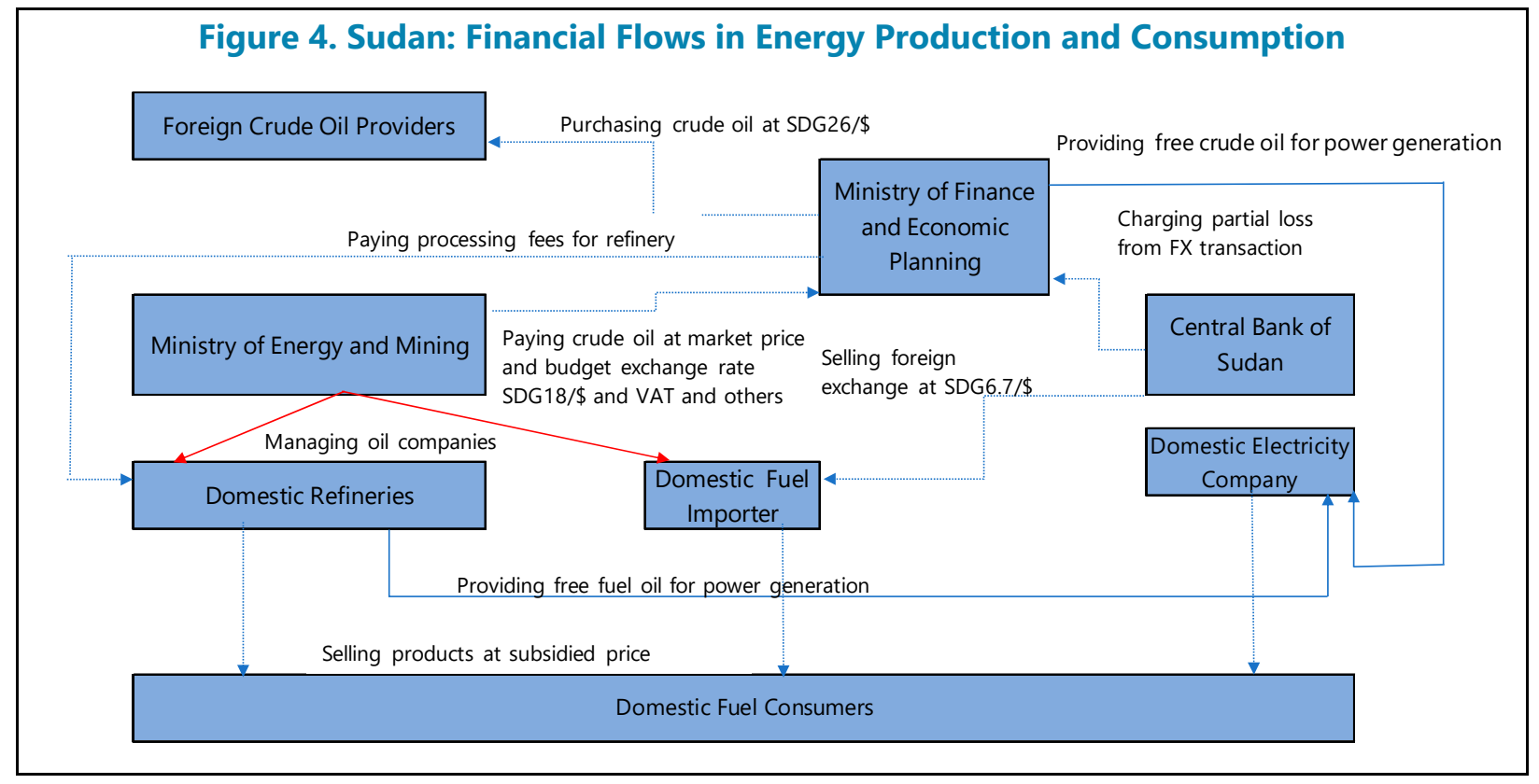

12. The MOFEP bears the full cost of fuel distribution. The MOEM is responsible for the cost of fuel production and import, while the MOFEP bears the cost of diesel and gasoline transportation and distribution from Port of Sudan and distribution center to different cities, which is about SDG 1.8 per ton per $\mathrm{km}$. In addition, the distribution margin charged by private companies are determined by the government and adjusted when companies need to increase their capital investment.

13. The MOEM pays various fees and taxes to the MOFEP on behalf the SOEs. Every month, a committee comprising of representatives from the MOFEP and MOEM meets to settle various claims between them. In summary, the MOFEP incurs charges to pay the refinery processing fees to the MOEM, while the MOEM will need to pay various fees and taxes from revenues of fuel product sales in the domestic market. Those fees and taxes include: (i) fuel stabilization fees based on the difference between current domestic fuel prices and those existing in 2013, currently at SDG 620 per ton for gasoline, SDG 536 per ton for diesel and SDG 80 per ton for LPG; (ii) development tax (13 percent of C\&F import price) for LPG and gasoline; (iii) custom fees at 10 percent of C\&F import price; (iv) fuel fees for both imported and domestically produced fuels, which is at SDG 960/ ton for LPG, SDG 5956.65 for gasoline and SDG 3207.96 per ton for diesel; (v) berth fees and crossing fees for LPG and gasoline imports, at SDG 41/ton and SDG 2.5/ton respectively; (vi) value added tax (VAT) (17 percent) and sea port VAT (SDG 7.41/ton) on diesel, gasoline and LPG imports, and VAT on domestically produced LPG, gasoline and diesel at rate of SDG 86.29 per ton for LPG, SDG 154.62 per ton for gasoline and SDG 85.06 for diesel; and (vii) supply of crude oil which is calculated at international price and converted to SDG by using SDG 18/US\$. 
14. Fuel consumption has increased steadily except in 2012 (Figure 5). Although private vehicle ownership in Sudan is relatively low, gasoline consumption volume increased on average at 12 percent in the past 20 years. Diesel consumption increase has been slightly smaller than gasoline at 8 percent on average.

\section{Fuel oils are provided at zero cost} for electricity generation. Sudan has both thermal and hydro power generating facility, but relatively cheap hydropower could not meet domestic demand, accounting for 60 percent of total electricity generation. The state-owned electricity generation company uses fuel oil from the refineries for power generation. In recent years as electricity consumption increased, the MOFEP also used crude oil from South Sudan $(14,000 \mathrm{bpd}$ in 2019) and imported fuel oil for power generation. However, the electricity company does not pay for the supply of fuel oil or crude oil. According to a World Bank report, in 2017 the revenue from sale of electricity could only cover 21 percent of the cost of operation, and the rest was subsidized because the average electricity tariff is only about US $\$ 0.007 / \mathrm{kWh}$ in 2018 (calculated using the official exchange rate of SDG 45/US\$), the lowest in Sub-Sahara Africa.

16. The power exchange agreement with Ethiopia also imposes additional costs on Sudan. As the state-owned power generation company does not have funds to invest in its equipment to improve electricity production, the government also agreed to provide 12000 barrels of gasoline per month to Ethiopia in exchange for electricity. Since Sudan already needs to import gasoline for its own consumption, they agreed that Ethiopia will send electricity to Sudan based on a gasoline import price marked down by US $\$ 20$. Therefore, the government bears additional costs for this transaction.

\section{The total amount of subsidies is neither transparent nor fully reflected in the} government's balance sheet. Given the complexity of various transactions between the MOFEP and MOEM, recording energy subsidies is very challenging in Sudan. The MOFEP's fiscal report only discloses energy subsidies on a partial netting basis. Because the government uses multiple exchange rates in these transactions, a substantial portion of subsidies arising from the use of different exchange rates are recorded the Central Bank's balance sheet. IMF staff estimate the total fuel subsidies by evaluating the gap between cost of production-which includes cost of supply at international prices, refining costs, transportation and distribution costs, tax payments and importing cost-and domestic retail prices. The estimated full fuel subsidies in 2019 are about SDG 215 billion, or 10.6 percent of GDP, in contrast with the SDG 52 billion reported as the outcome for 2019 budget.

\section{While energy subsidies are huge and costly, they benefit mostly high-income} households and neighbor countries. The 2014/15 National Household Budget and Poverty Survey 
(NHBPS) states that only 5.7 percent and 2.6 percent of households, respectively, own motor vehicles and motor cycles in Sudan. More broadly, a World Bank study concludes that energy subsidies disproportionately benefit the rich, because the top 20 percent of households receive more than eight times the fuel subsidy received by the bottom 40 percent, and on average, fuel expense makes up only 1.5 percent of total household expense. Moreover, cheaper fuel prices have motivated smuggling of fuels to neighbor countries.

\section{Removing Energy Subsidies and Reforming Oil Sector Governance}

\section{International experience shows that successful removal of energy subsidies has}

some common ingredients. Fuel price increases have often led to widespread public protests in part due to lack of confidence in the ability of government to shift the savings from removal of subsidies to programs that would compensate the poor and middle class for the higher energy prices. An IMF paper which identified 28 country reform episodes found that 12 countries have successfully reduced subsidies, 11 were partially successful —often because of reversals or incomplete implementation and 5 were unsuccessful. These country experiences suggest some ingredients are needed for a success reform as following:

- A comprehensive energy sector reform plan with clear long-term objectives incorporating an analysis of the impact of reforms;

- Transparent and extensive communication and consultation with stakeholders;

- Phasing-in price increases over time;

- Improving the efficiency of state-owned enterprises to reduce producer subsidies;

- Measures to protect the poor through targeted cash or near-cash transfer, or, if this option is not feasible, a focus on existing targeted programs that can be expended quickly; and

- Institutional reforms that depoliticize energy pricing, such as the introduction of automatic pricing mechanisms.

20. Some specifics need to be considered for Sudan's energy subsidy reforms. Sudan has persistent large macroeconomic imbalances due to past mismanagement and lack of external investment and financing. The weak economic condition and the continued depreciation of the Sudanese currency would complicate energy subsidy reforms. On the other hand, the recent regime change has created a window of opportunity for fundamental reforms. Therefore, energy subsidy reform should be included in a comprehensive economic reform package which should also tackle exchange rate reforms. The rather high poverty ratio and large gaps between domestic fuel prices and break-even prices in Sudan also means that removal of subsidies should be conditional of other key policy actions. Notably, an expanded social safety net and an extensive information and communication campaign need to be in place prior to subsidy reforms. 
21. The government should also reform the governance of the oil sector. This includes reforming SOEs to allow them to operate on commercial basis so that they would be incentivized to have a long-term development targets and investment strategy; streamlining the function of the MOEM and returning it to a genuine ministry in charge of regulating this sector and providing strategic views on the development of energy sector in Sudan; establishing clear lines of responsibility between MOFEP and MOEM with regard of energy sector's regulation; and finally improving transparency and enhancing auditing in the oil sector to allow more public analysis and scrutiny. 


\section{References}

Ndip A. E., 2019, "Fuel Subsidy Reform in Sudan: An Assessment of the Direct Welfare Impact on Households" (Washington: World Bank).

Clements, B., D. Coady, S. Fabrizio, S. Gupta, T. Alleyne, and C. Sdralevich, 2017 "Energy Subsidy Reform-Lessons and Implications" (Washington: International Monetary Fund).

U.S. Energy Information Administration, 2019, "Country Analysis Brief: Sudan and South Sudan" Luke Anthony Patey, 2007, "State Rules: Oil Companies and Armed Conflict in Sudan" Routledge Taylor and Francis Group, Third World Quarterly, Vol. 28, No. 5, 2007, pp 9971016

2010 "Crude Days Ahead? Oil and the Resource Curse in Sudan", African Affairs, 2010 109/437,617-636

Fatal Transactions, 2008, "Sudan' s Oil Industry: Facts and Analysis"

World Bank: 2019, "Sustainability of Sudan's Electricity Sector" (Washington: World Bank)

Central Bureau of Statistics of Sudan, 2017, "Sudan National Household Budget and Poverty Survey 2014/15" CBS Report No. 11, 2017. 


\section{FINANCIAL SYSTEM IN SUDAN ${ }^{1}$}

1. Commercial banks dominate the financial system in Sudan. The financial system includes 37 banks and several non-bank financial institutions-mainly insurance companies and small-scale microfinance institutions, with limited size relative to the economy. Four state-owned banks (with 14 percent of total banking assets) operate as specialized banks, focusing on providing credit to targeted sectors, such as agriculture or infrastructure development. The Central Bank of Sudan (CBOS) and state governments also hold small shares in other joint-venture commercial banks. Seven foreign banks are registered as branches in Sudan (accounting for 23 percent of total banking assets), with owners from Gulf states (UAE, Jordan, Saudi Arabia, and Qatar) and neighboring countries (Egypt, Lebanon, South Sudan and Ghana). As of November 2019, total assets of banking sector were about SDG 505 billion, accounting for 25 percent of GDP. The CBOS is responsible for the regulation of the financial system but information on non-bank financial institutions is limited. The CBOS operates a real time gross settlement system with participation by commercial banks, with very limited turnover volume. Commercial banks have established a small-scale liquidity fund to provide liquidity support to banks in need (Figure 1).

Figure 1. Sudan: The Structure of Financial System of Sudan 1/

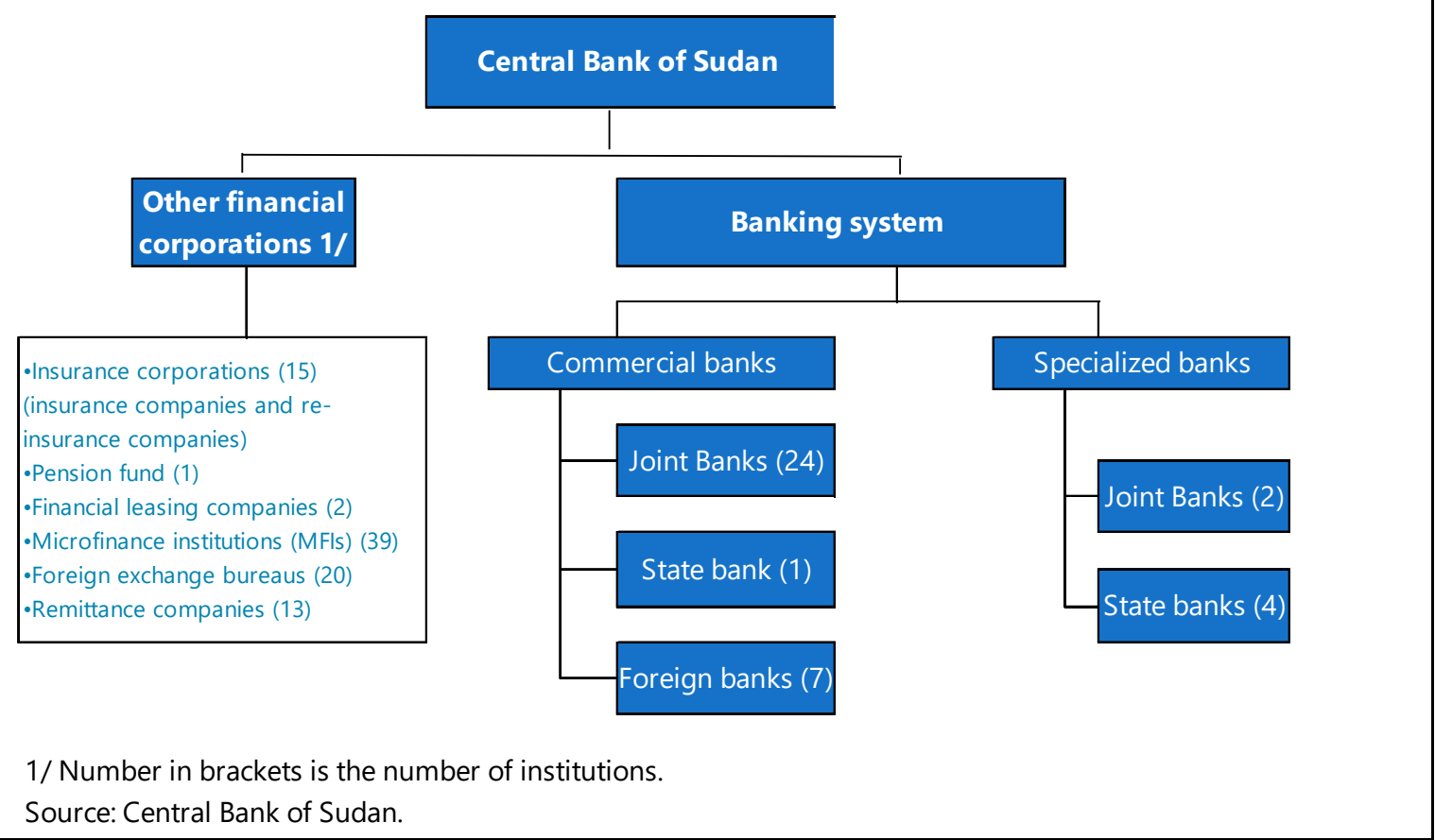

2. Continued weak economic performance has constrained financial inclusion. Sudan has the lowest financial inclusion in Sub-Saharan Africa, with only 15.3 percent of adults (aged 15+)

\footnotetext{
1 Prepared by Qiaoe Chen.
} 
having a financial account. ${ }^{2}$ Cash is widely used in retail payment as the scarcity of bank notes in 2018 has negatively impacted the public confidence in the financial sector. The cash to deposit ratio in Sudan rose sharply from about 45 percent before 2018 to 79 percent in November 2019. User behaviors also persistently favor cash products because of low financial awareness and literacy.

3. The banking sector is highly concentrated. The five largest banks account for 55 percent of total assets, including one state-owned bank, Industrial Development Bank, and four other joint venture banks which are held by private sector, including foreign investors. The largest bank, Bank of Khartoum (17.3 percent market share), is majority owned by UAE investors, and has no state ownership. Inter-connection among banks are very limited.

\section{The banking sector operates in line} with Islamic law. Since 1984, all banks have been required to operate according to Islamic principles. The CBOS has a Higher Sharia Supervisory Board (established in 1992) that ensures compliance with Sharia law, and every bank has its own Sharia Supervisory Board. Commercial banks provide traditional banking services by attracting deposits, granting financing and holding liquidity in line with Islamic principles.

\section{Bank lending is directed largely to wholesale banking business, and evenly spread across the main economic sectors.} Lending is the main business model, accounting for more than 40 percent of banks' total assets, but there is quite big variance, ranging from 3.6 percent to 65 percent. Lending to nonfinancial corporations account for more than 60 percent of the total credit, while household lending is less than 20 percent. Lending to economic sectors are quite even, with industry, agriculture and services each accounting for about 20 percent of total credit (Figures 2 and 3). Credit in foreign currency is relatively small, about 7.8 percent of total credit, with one bank accounting for more than 50 percent of the total.
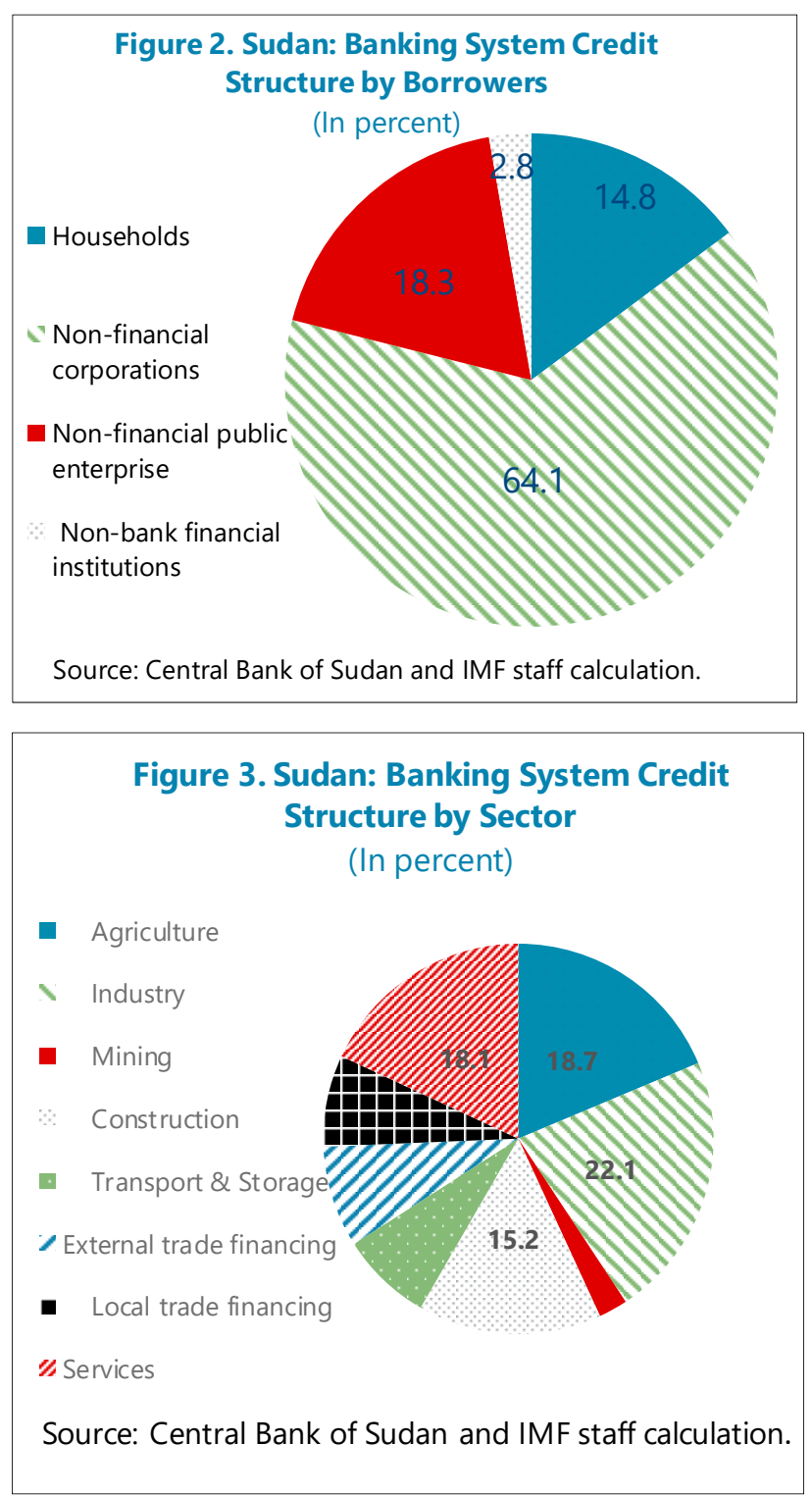

\footnotetext{
2 Based on the 2014 Global Findex result.
} 
6. The banking sector remains vulnerable with several banks undercapitalized. The CBOS sets the minimum capital adequacy ratio (CAR) at 12 percent of risk-weighted assets, but several banks' CARs have been below the requirement for many years, with some having negative CARs. In addition, the non-performing loans (NPL) are underestimated since the Central Bank only defines the past due unpaid installments NPLs rather than the whole loan value. The Central Bank borrowed about US $\$ 2$ billion foreign exchange from commercial banks years ago but has not been able to repay the banks. These illiquid foreign exchange assets are recorded as excess reserves in the central bank's balance sheet.

7. Banking regulation and supervision capacity need to be improved. According to the World Bank' s assessment, Central Bank supervision is constrained due to limited resources and capacity, the supervision approach is fragmented and lacks understanding of banks' risk profiles, corrective action is not effective and prudential requirements are incomplete and outdated. Implementation of IMF TA on supervision has been slow. 